\title{
Floristic composition and variation in late Paleocene to early Eocene floras in North America
}

\author{
Kathleen B. Pigg \& Melanie L. DeVore
}

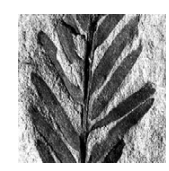

\begin{abstract}
The late Paleocene and early Eocene megafossil floras in North America are found primarily in the Williston, Green River, Powder River, Bighorn, and Alberta Basins of the northern Rocky Mountains and Western Interior. A few rare sites occur in the Mississippi Embayment of the Southeast. In contrast to the abrupt floristic changes seen at the K/T boundary, these floras document a gradual transition in species turnover, or, in the case of the Bighorn Basin, a long-term decrease in taxonomic diversity. This gradual transition is also in marked contrast to the rapid speciation among mammals of the early Eocene. Both preservation, and ability to place these floras within a temporal scale, determine how useful they are in assessing floristic changes across the Paleocene-Eocene transition. In some regions such as the Bighorn Basin of Wyoming precise stratigraphic control has allowed for documentation of paleoclimate change at a highly resolved temporal scale. At others, such as the Almont flora of the Williston Basin in North Dakota, exceptional preservation has provided the basis for describing individual taxa with the precision necessary to better understand their evolutionary and biogeographical histories. This study examines well-known plant taxa in the late Paleocene and early Eocene in the context of their depositional settings and temporal and spatial distribution. Integration of paleoecological and taxonomic studies is critical to understanding the evolutionary and depositional history of early Paleocene vegetation of North America. - Key words: Almont/Beicegel Creek flora, Bighorn Basin, Eocene thermal maximum, Fort Union Formation, Golden Valley flora, Joffre Bridge, Paleocene/Eocene Transition.
\end{abstract}

PigG, K.B. \& DEVore, M.L. 2010. Floristic composition and variation in late Paleocene to early Eocene floras in North America. Bulletin of Geosciences 85(1), 135-154 (1 figure, 6 tables). Czech Geological Survey, Prague. ISSN 1214-1119. Manuscript received April 7, 2009; accepted in revised form October 5, 2009; published online January 8, 2010; issued xxxx xx, 2010.

Kathleen B. Pigg (corresponding author), School of Life Sciences, Arizona State University, PO Box 874501, Tempe AZ 85287-4501 USA; kpigg@asu.edu・Melanie L.DeVore, Department of Biological \& Environmental Sciences, Georgia College \& State University, 135 Herty Hall, Milledgeville, GA 31062-0001, USA; melanie.devore@gcsu.edu

In North America, late Paleocene to early Eocene megafossil floras are best documented for nonmarine strata of the Williston, Green River, Powder River, Bighorn, and Alberta (Western Canadian) Basins of the northern Rocky Mountains and Western Interior. In the Mississippi Embayment of the Southeast, confidently dated sedimentary sequences of these ages are rare. Interest in the Paleocene floras of North America has focused on floristic changes associated with the two major transitions, the K-T boundary at the beginning and the Paleocene to Eocene transition at the end. Whereas dramatic changes in floral diversity have been reported in connection with the K-T boundary (Wolfe \& Upchurch 1987; K. Johnson 1992, 2002; Nichols \& K. Johnson 2008), in the Paleocene to Eocene transition rates of extinction and origination were more gradual. This transition did not mirror the rapid Eocene radiation of modern mammals (Wing et al. 1995; Graham 1999). With rare exceptions, floras of the rest of the Paleocene have been regarded as relatively low diversity assemblages (Wing 1998, K. Johnson \& Ellis 2002). Nevertheless, they are essential for understanding the sources of major plant families that radiated later.

Early studies from the 1860 's to early $20^{\text {th }}$ century (e.g., Newberry 1868; Lesquereux 1874, 1878; Ward 1885; Knowlton 1893, 1919) focused on identifying the living relatives of fossil plants and reconstructing Tertiary plant communities based on the ecological attributes of their extant descendants [Nearest Living Relative (NLR) techniques; Graham 1999]. From the mid-Century on, floristic studies documented many of the floras of western North America (see Graham 1999) and techniques for analyzing leaf morphological variation in relation to climate were developed [e.g., Leaf Margin Analysis (LMA), Climate Leaf Analysis Multivariate Program (CLAMP)]. By the 1980s these techniques were used to score leaf types in fossil floras in order to estimate paleoclimate (Wolfe 1987). More recently, multiple proxies (carbon isotopes, pollen, leaf physiognomy) are placed in the context of radiometric and 
biostratigraphic frameworks such as the North American Land Mammal Ages (NALMA, Wood et al. 1941, Woodburne 2004) to better correlate the responses of terrestrial ecosystems to the well-known marine systems. At the same time, detailed taxonomic studies of fossil plants have become increasingly valuable to the broader systematics community because they can be used to date nodes of divergence for clades within phylogenetic trees. In particular, well-preserved and complete specimens can serve as "key taxa" in phylogenetic reconstruction (Table 1).

As a consequence of the specialization of both of these areas, contemporary Tertiary paleobotanists have tended to focus on either paleoecology or systematics. Rarely have these various studies been integrated to present a comprehensive view of both the ecological response and evolutionary significance of Paleocene-Eocene plants. This paper reviews major studies of these two types and aims to help link these areas by (1) outlining the regional and depositional contexts of major late Paleocene and early Eocene megafossil floras in North America, (2) documenting "key taxa" that provide comprehensive taxonomic and phylogenetic information, and noting newly recognized taxonomic affinities; and (3) tracking the spatial and temporal distribution of selected genera that show major biogeographic patterns between the Paleocene and the Eocene.

\section{Overview of the floras}

\section{Mississippian Embayment, Southeastern North America}

Despite a rich plant megafossil record from the Eocene Wilcox and Claiborne Groups, sites representing the Paleocene-Eocene transition are extraordinarily rare in eastern North America (Graham 1999, Danehy et al. 2007). In general, floras from both the Atlantic Seaboard and the Gulf Coast occur in isolated clays and lignites that cannot be placed within the clear temporal framework required for tracing floristic changes across the Paleocene-Eocene transition. In the Southeast, the best documentation of the Paleocene-Eocene transition is based on pollen data that is currently being evaluated (Harrington 2003, 2004, 2008; Harrington \& Jaramillo 2007).

The Paleocene-Eocene thermal maximum (PETM) probably has a position within the upper Tuscahoma Formation in Mississippi as estimated by Harrington et al. (2005) based on palynomorph data from the Harrell Core. An early Eocene leaf flora from the Red Hot Truck Stop locality in Meridian, Mississippi is notable since it has been dated to the earliest Eocene and may fall within the PETM (Table 2). This site has a section exposing both the Tuscahoma (Paleocene) and Bashi (Eocene) Formations that have been placed into a chronological framework based locally on pollen, dinoflagellates, mammals and sequence stratigraphy as well as correlation with calcareous nannoplankton, and foraminifera (Danehy et al. 2007).

Fossil plants at the Red Hot Truck Stop occur within the basal Bashi Formation in a setting interpreted to represent a coastal environment that includes near-shore marine, tidal channels and estuary facies (Ingram 1991). The vegetation is considered to be tropical to subtropical and includes 18 leaf species and morphotypes. Notable elements are the climbing fern Lygodium, leaves of Platycarya (Juglandaceae), Rhus (Anacardiaceae), Fabaceae, Lauraceae, and Myrtaceae (Danehy et al. 2007). Leaves assigned to the malphigian family Ochnaceae represent some of the earliest megafossil records of the family (see also Pigg et al. 2005). Fruits of Icacinaceae and Juglandaceae are also known.

The Red Hot Truck Stop has significant potential to serve as a touchstone for reconstructing the PaleoceneEocene floristic changes in the Mississippian Embayment. This locality also provides a rare megafossil datum for biogeographical relationships between eastern and western North American floras during the Paleocene-Eocene transition since several of the taxa described from the flora are also found in the West (e.g., Platycarya, Ochnaceae, Myrtaceae, Danehy et al. 2007).

\section{Western occurrences}

In contrast to eastern North America, the Western Interior and Rocky Mountain regions provide a significant number of Paleocene and Eocene floras from sequences deposited within basins that can be placed within a chronological framework. Several of these sequences span the Paleocene-Eocene boundary. The easternmost of these is the central Williston Basin of North and South Dakota, Montana and the southern part of the Canadian provinces of Saskatchewan and Manitoba. In the southern region of the Williston Basin the Golden Valley flora localities span the Paleocene to Eocene boundary (Hickey 1977). To the north the Ravenscrag flora of Puercan-Torrejonian age has been described from Saskatchewan (McIver \& Basinger 1993). The Bighorn, Green River, and Powder River Basins yield floras spanning the Paleocene-Eocene transition (Hickey 1980; Wing 1997, 1998; Wing et al. 1995, 2000; Gemmill \& K. Johnson 1997; Wilf 2000). These last three basins have been the focus of numerous studies documenting floristic changes across the Paleocene-Eocene transition.

Other floras are of note because of the fidelity of preservation and details of taxonomic value. The Alberta Basin contains important floras at Genesee (Chandrasekaram 1974), Joffre Bridge and Munce's Hill near Red Deer, Alberta (Hoffman \& Stockey 1999, Hoffman 2002). Detailed 
Table 1. Key taxa. Late Paleocene and early Eocene taxa with detailed morphological and taxonomic information known. Locality abbreviations: in the Mississipian Embayment (ME): Red Hot Truck Stop (rhts); Bighorn Basin (BH); Green River Basin (GR); Powder River Basin (PR); Wind River Basin (WR); in the Williston Basin: Almont (al); Beicegel Creek (bc); Golden Valley (gv); Ravenscrag (rv); in the Alberta Basin (AB): Genesee (ge); Joffre Bridge (jb); Munce's Hill (mh); * indicates numerous floras. MT - Montana, WY - Wyoming.

\begin{tabular}{|c|c|c|c|}
\hline Family & Taxon & Basin: Flora & Citation \\
\hline Ricciaceae & Ricciopsis speirsae & $A B: j b$ & Hoffman \& Stockey (1997) \\
\hline Ophioglossaceae & Botrychium wightonii & AB: ge & Rothwell \& Stockey (1989) \\
\hline Polypodiaceae & Onoclea sensibilis & $\mathrm{AB}: \mathrm{mh}$ & Rothwell \& Stockey (1991) \\
\hline Blechnaceae & Woodwardia sp. & WB: bc, rv & McIver \& Basinger (1993), Pigg et al. (2006) \\
\hline Schizeaceae & Lygodium kaulfussi & ME: rhts; $\mathrm{BH}^{*}$ & Manchester \& Zavada (1987) \\
\hline Thelypteridaceae & Speirsopteris orbiculata & $\mathrm{AB}: \mathrm{mh}$ & Stockey et al. (2006) \\
\hline Azollaceae & Azolla stanleyi & $\mathrm{AB}: \mathrm{jb}$ & Hoffman \& Stockey (1994) \\
\hline Isoetaceae & Isoetes horridus & WB: bc, gv, rv & Brown 1962, Hickey (1977), McIver \& Basinger (1993) \\
\hline Cycadaceae & Eostangeria pseudopteris & $\mathrm{GR}^{*}$ & Kvaček \& Manchester (1999) \\
\hline Cupressaceae & Metasequoia foxii & $\mathrm{AB}: \mathrm{mh}$ & Falder et al. (1999, Stockey et al. (2001) \\
\hline Betulaceae & Cranea wyomingensis & BH PR WR* & Manchester \& Chen (1996) \\
\hline Betulaceae & Palaeocarpinus aspinosa & $\mathrm{BH}, \mathrm{GR}$ & Manchester \& Chen (1998) \\
\hline Betulaceae & Palaeocarpinus dakotensis & WB: al, bc & Manchester et al. (2005) \\
\hline Betulaceae & Palaeocarpinus joffrensis & $\mathrm{AB}: \mathrm{mh}$ & Sun \& Stockey (1992) \\
\hline Celtidaceae & Celtis aspera & $\mathrm{BH}$ & Manchester et al. (2002) \\
\hline Cercidiphyllaceae & Joffrea speirsae & $\mathrm{AB}: \mathrm{jb}$ & Stockey \& Crane (1983); Crane \& Stockey $(1985,1986 a)$ \\
\hline Cornaceae & Cornus sp. & WB: al, bc & Xiang et al. (2003) \\
\hline Cornaceae & Mastixia & $\mathrm{BH}$ & Tiffney \& Haggard (1996) \\
\hline Hamamelidaceae & Hamawilsonia boglei & WB: al & Benedict et al. (2008) \\
\hline Juglandaceae & Cyclocarya brownii & WB: al, bc & Manchester \& Dilcher (1982) \\
\hline Juglandaceae & Polyptera manningii & MT WY & Manchester \& Dilcher (1997) \\
\hline Lemnaceae & Limnobiophyllum & WB: rc; AB: jb & Stockey et al. (1997) \\
\hline Myrtaceae & Paleomyrtinea sp. & WB: al, bc & Pigg et al. (1993) \\
\hline Nymphaeaceae & Nuphar wutuensis & WB: al & Chen et al. (2004) \\
\hline Nymphaeaceae & Susiea newsalemae & WB: al & Taylor et al. (2006) \\
\hline Nyssaceae & Amersinia, Beringiaphyllum & WB: al, bc, gv & Manchester et al. (1999) \\
\hline Nyssaceae & Browniea & WB: rv; WY & Manchester \& Hickey (2007) \\
\hline Nyssaceae & Davidia antiqua & WB: al & Manchester (2002a) \\
\hline Polygalaceae & Paleosecuridaca curtisii & WB: al, bc & Pigg et al. (2008) \\
\hline Sapindaceae & Aesculus hickeyi & WB: al, bc, gv & Manchester (2001) \\
\hline Trochodendraceae & Nordenskioldia, Zizyphoides & WB: al, bc & Crane et al. (1991) \\
\hline
\end{tabular}

systematic studies from these Alberta sites include (1) at Genesee, Botrychium; (2) at Munce's Hill, the filicalean ferns Onoclea, Metasequoia, and Palaeocarpinus; and, (3) at Joffre Bridge, Ricciopsis, Azolla, Joffrea, Platanaceae and Limnobiophyllum.

In the Williston Basin, the Almont flora of central North Dakota (Crane et al. 1990) includes Ginkgo, taxodiaceous conifers, Taxaceae, Cyclocarya (Juglandaceae), Trochodendraceae, Myrtaceae, several cornalean taxa, Aesculus, Acer, Palaeocarpinus (Betulaceae), Hamawilsonia (Hamamelidaceae), Paleoactaea (Ranunculaceae),
Paleosecuridaca (Polygalaceae), and Nuphar and Susiea (Nymphaeaceae, Table 1, 3). This flora which has excellently preserved fruits and seeds, along with leaves is still under study (Manchester et al. 2004; Pigg \& DeVore 2005, Pigg et al. 2008a, b; Benedict et al. 2007, 2008; Taylor 2006). Beicegel Creek is a second flora similar to Almont in taxonomic composition but with better anatomical preservation that allows for preparation with cellulose acetate peels and a more detailed stratigraphic context (DeVore $e t$ al. 2004; Pigg \& DeVore 2003, 2005; Pigg et al. 2006, 2008a). 
Table 2. Major floras discussed in text, excluding those of Bighorn Basin. Abbreviations: AL - Alberta; CO - Colorado; MS - Mississippi; MT - Montana; ND - North Dakota; SK - Saskatchewan; UT - Utah; WY - Wyoming; n - north; s - south; e - east; w -west; E - Early; M - Middle; L - Late. Data from ${ }^{1}$ Danehy et al. 2007; ${ }^{2}$ Wilf 2000; ${ }^{3}$ Hickey $1977 ;{ }^{4}$ McIver \& Basinger $1993 ;{ }^{5}$ Crane et al. 1990 and others (see Table 3 ); ${ }^{6}$ Manchester et al. 2004 and others (see Table 3); ${ }^{7}$ Stockey et al. 2006; ${ }^{8}$ Hoffman 2002; Hoffman \& Stockey 1997; ${ }^{9}$ Chandrasekaram 1974.

\begin{tabular}{|c|c|c|c|c|c|c|c|}
\hline Floras & Basin & $\begin{array}{l}\text { Location } \\
\text { No. sites }\end{array}$ & $\begin{array}{l}\text { Age (Ma) } \\
\text { NAMLA }\end{array}$ & $\begin{array}{l}\text { Formation } \\
\text { (Member) }\end{array}$ & Depositional environments & $\begin{array}{l}\text { MAT }\left({ }^{\circ} \mathrm{C}\right) / \\
\text { Vegetation }\end{array}$ & $\begin{array}{l}\text { No. Species/ } \\
\text { Morphotypes }\end{array}$ \\
\hline $\begin{array}{l}{ }^{1} \text { Red Hot } \\
\text { Truck Stop }\end{array}$ & $\begin{array}{l}\text { Mississippi } \\
\text { Embayment }\end{array}$ & $\begin{array}{l}\text { MS } \\
1 \text { site }\end{array}$ & $\begin{array}{l}55.8 \text { earliest } \\
\text { Wasatchian }\end{array}$ & Bashi (base) & $\begin{array}{l}\text { tidal channels } \\
\text { estuaries }\end{array}$ & $\begin{array}{l}\text { tropical to } \\
\text { subtropical }\end{array}$ & $\begin{array}{l}18 \text { leaf \& } 2 \\
\text { fruit types }\end{array}$ \\
\hline${ }^{2}$ Green River & $\begin{array}{l}\text { Green River } \\
\& \text { subbasins }\end{array}$ & $\begin{array}{l}\text { swWY } \\
115 \text { sites }\end{array}$ & $\begin{array}{l}\text { Tiffanian-E } \\
\text { Bridgerian }\end{array}$ & $\begin{array}{l}\text { Fort Union- } \\
\text { Wasatchian }\end{array}$ & $\begin{array}{l}\text { alluvial, } \\
\text { one lacustrine }\end{array}$ & & \\
\hline${ }^{2}$ Bison Basin & Great Divide & 14 sites & 56.2-60 Tiffanian & Fort Union & alluvial & $\begin{array}{l}11.7 \text { humid } \\
\text { warm temperate }\end{array}$ & 29 species \\
\hline $\begin{array}{l}{ }^{2} \text { Clarkforkian } \\
\& \text { Big Multi }\end{array}$ & Green River & $\begin{array}{l}49 \text { sites } \\
15 \text { sites }\end{array}$ & 55.7 Clarkforkian & $\begin{array}{l}\text { upper Fort Union } \\
\text { lower Wasatch }\end{array}$ & alluvial & $\begin{array}{l}14.4, \\
18.6 \text { humid } \\
\text { subtropical }\end{array}$ & $\begin{array}{l}48 \text { species } \\
29 \text { species }\end{array}$ \\
\hline $\begin{array}{l}{ }^{2} \text { Wasatch Main } \\
\text { Body }\end{array}$ & Green River & 6 sites & $\begin{array}{l}\text { Graybullian to } \\
\text { Lysitian }\end{array}$ & $\begin{array}{l}\text { uppermost } \\
\text { Fort Union }\end{array}$ & alluvial & dry mild & 13 species \\
\hline${ }^{2}$ Latham & Green River & 7 sites & possibly Lysitian & $\begin{array}{l}\text { Wasatch (Ranger } \\
\text { Ranch) }\end{array}$ & alluvial & $\begin{array}{l}16.4 \text { mild } \\
\text { humid }\end{array}$ & 17 species \\
\hline${ }^{2}$ Sourdough & Green River & 31 sites & $\begin{array}{l}52.8 \text { probably } \\
\text { E Lostcabinian }\end{array}$ & $\begin{array}{l}\text { Wasatch (upper } \\
\text { Ranger Ranch ) }\end{array}$ & alluvial & 21.3 humid & 61 species \\
\hline${ }^{2}$ Niland Tongue & Green River & 5 sites & Lostcabinian & Wasatch & alluvial & 23 warm & 24 species \\
\hline${ }^{2}$ Little Mountain & Green River & 3 sites & E Bridgerian & Green River & lacustrine & 19.6 hot arid & 59 species \\
\hline $\begin{array}{l}{ }^{3} \text { Golden Valley } \\
\text { Bear Den }\end{array}$ & Williston & $\begin{array}{l}\text { w ND } \\
\text { sites }\end{array}$ & Clarkforkian & $\begin{array}{l}\text { Golden Valley } \\
\text { (Bear Den) }\end{array}$ & lowland forest swamp & $\begin{array}{l}\text { warm temperate } \\
\text { forest }\end{array}$ & 41 species \\
\hline $\begin{array}{l}{ }^{3} \text { Golden Valley } \\
\text { Camels Butte }\end{array}$ & Williston & $\begin{array}{l}\text { w ND } \\
\text { sites }\end{array}$ & 56 Wasatchian & $\begin{array}{l}\text { Golden Valley } \\
\text { (Camels Butte) }\end{array}$ & alluvial plain & subtropical & 37 species \\
\hline${ }^{4}$ Ravenscrag & Williston & $\begin{array}{l}\text { sw SK } \\
\text { sites }\end{array}$ & $\begin{array}{l}\text { Puercan-Torrejon } \\
\text { ian }\end{array}$ & Ravenscrag & $\begin{array}{l}\text { alluvial plain meandering streams } \\
\text { ponds, swamps \& lowland forest }\end{array}$ & $\begin{array}{l}\text { polar broadleaf } \\
\text { deciduous forest }\end{array}$ & $\begin{array}{l}46 \text { species } \\
23 \text { unknown }\end{array}$ \\
\hline${ }^{5}$ Almont & Williston & $\begin{array}{l}\text { c ND } \\
1 \text { site }\end{array}$ & $\begin{array}{l}57 \\
\text { Tiffanian } 3\end{array}$ & Sentinel Butte & $\begin{array}{l}\text { clay lens channel fills altered by } \\
\text { iron \& silica solution }\end{array}$ & $\begin{array}{l}\text { warm temperate } \\
\text { forest }\end{array}$ & $\begin{array}{l}48 \text { species } \\
28 \text { families }\end{array}$ \\
\hline${ }^{6}$ Beicegel Creek & Williston & $\begin{array}{l}\mathrm{W} \text { ND } \\
5 \text { sites }\end{array}$ & $\begin{array}{l}57 \\
\text { Tiffanian } 3\end{array}$ & Sentinel Butte & $\begin{array}{l}\text { floodplain;fluvial \& abandoned } \\
\text { channel; swamp; cravasse splay }\end{array}$ & $\begin{array}{l}\text { warm temperate } \\
\text { forest }\end{array}$ & 30 species \\
\hline 7'Munce's Hill & Alberta & $\begin{array}{l}\text { sc } \mathrm{AL} \\
1 \text { site }\end{array}$ & $\begin{array}{l}57 \\
\text { Tiffanian T4 }\end{array}$ & Paskapoo & wetland forest community & $\begin{array}{l}\text { polar broadleaf } \\
\text { deciduous forest }\end{array}$ & 9 species \\
\hline $\begin{array}{l}{ }^{9} \text { Joffre Bridge } \\
\text { Roadcut }\end{array}$ & Alberta & $\begin{array}{l}\text { sc } \mathrm{AL} \\
1 \text { site }\end{array}$ & $\begin{array}{l}58-60 \\
\text { Tiffanian T3 }\end{array}$ & Paskapoo & $\begin{array}{l}\text { floodplain; fluvial \& abandoned } \\
\text { channel; swamp; cravasse splay }\end{array}$ & $\begin{array}{l}\text { polar broadleaf } \\
\text { deciduous forest }\end{array}$ & $\begin{array}{l}28 \text { genera } \\
18 \text { families }\end{array}$ \\
\hline${ }^{9}$ Genessee & Alberta & $\begin{array}{l}\text { sc } \mathrm{AL} \\
1 \text { site }\end{array}$ & Tiffanian & Paskapoo & wetland forest community & $\begin{array}{l}\text { polar broadleaf } \\
\text { deciduous forest }\end{array}$ & 19 species \\
\hline
\end{tabular}

\section{Stratigraphic and depositional settings in Western North America}

Numerous studies of the Paleocene-Eocene transition in continental strata in North America have focused on sequences present in the Bighorn and Williston Basins (Table $2,4,5)$. A brief explanation of the origin of the basins in the Rocky Mountains, as well as the region of the Williston Basin to the east of the Rockies, is useful for understanding the Paleocene-Eocene depositional environments and stratigraphy.

During the Cretaceous, a large foreland sedimentary basin spanned from the Arctic Ocean to the Gulf of Mexico. At the end of the Cretaceous and through the Eocene, crustal shortening and deformation associated with the
Laramide orogeny dissected the foreland basin into a series of smaller basins that became well established by the end of the Paleocene (Fig. 1; Hamilton 1988, Flores et al. 1994, Perry et al. 1991, R. Johnson \& Flores 1998). East of the Rocky Mountains, arches associated with Laramide deformation, including the Black Hills and Bighorn Mountains, influenced the geometry of both the Powder River and Williston Basins. Mid-continental arches, sometimes referred to as "plainstype folding", developed in the region now occupied by Kansas, Minnesota, Nebraska, North Dakota, Oklahoma and Texas. The origin of mid-continental arches is estimated to be at least Late Paleozoic, even older, and they were probably activated during the Laramide orogeny (Bunker et al. 1988, Tikoff \& Mason 2001). 


\section{Bighorn Basin}

The Bighorn Basin is located adjacent to the Pryor Bighorn Mountain Block to the east with the downdropped Red Lodge Block and uplifted Beartooth Block oriented perpendicular to its western border. The Columbus "Shelf" separates the Bighorn Basin from the Crazy Mountains Basin towards the northwest. These structural areas were elevated during the mid-late portion of the Laramide orogeny, with the uplift of the Beartooth Mountains occurring during the middle to late Paleocene (Beck et al. 1988), while that of the Bighorn Mountains is dated at late Paleocene. During the early Eocene the southern Bighorn Mountains were thrust towards the southeast. Clearly, the tectonic history had an influence on depositional environments located within the basin, impacting the types and directions of fluvial systems present.

Thick sequences of clastics (sandstones, mudstones), lignites, and freshwater carbonates were deposited during the Paleocene and early Eocene (Gingerich 1983). The thick $(3000 \mathrm{~m})$, Paleocene sequences of clastics and lignites present in the Bighorn Basin are assigned to the Fort Union Formation. The gray-light brown beds of the Fort Union Formation are overlain by the oxidized mudstone dominated Willwood Formation (Paleocene to early Eocene, T. Brown \& Kraus 1981). Based on geometry, Wing (1984), recognized two distinct sedimentary units within the Willwood Formation, lenticular bodies and tabular bodies, and characterized the plant fossil assemblages within each. The lenticular bodies, were interpreted as reflecting deposition within abandoned fluvial channels while the tabular bodies, composed of underbeds, carbonaceous shales, interlaminated silts and shales, and overlying sand bodies, were thought to be the remains of backswamp deposits on a distal floodplain (Wing 1984). Further study of the backswamp deposits (Davies-Vollum \& Wing 1998) demonstrated that they are prevalent in the lower and upper Willwood Formation, but are conspicuously absent in the middle portion. An explanation for this lack of backswamp deposits in the middle Willwood Formation is that enhanced rates of sediment accumulation resulted in organic material becoming dispersed within the sediments and then being degraded in a drier climatic regime before preservation could occur. A combination of climatic and tectonic influences was responsible.

A comprehensive magnetostratigraphic framework has been developed recently for the Bighorn Basin (Clyde et al. 2007), making it possible to compare interpretations of faunal and floral turnovers and correlate other paleoclimatic data with worldwide databases. One of the outcomes of this study was the documentation of the time-transgressive elements of basin formation and demonstration that the northern and southern parts of the basin had dis-

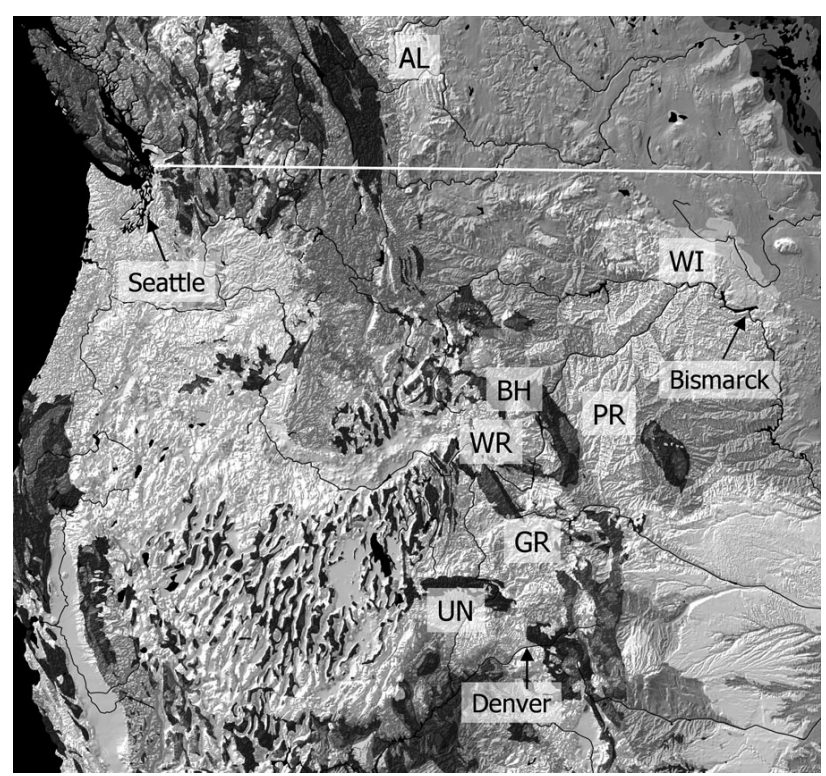

Figure 1. General overview of major Paleocene-Eocene basins in the Rocky Mountains and Great Plains of western North America. Abbreviations: AL - Alberta, BH - Bighorn, GR - Green River, PR Powder River, UN - Uinta, WI - Williston, WR - Wind River. The cities of Denver, Colorado; Seattle, Washington, and Bismarck, North Dakota are indicated for context. Redrawn from Barton et al. (2009).

tinct depositional histories, thus permitting interpretation of regional elements influencing the plant fossil record. Key taxa from the Bighorn Basin include the following: Palaeocarpinus aspinosa and Cranea (Betulaceae), Polyptera (Juglandaceae), Mastixia (Cornaceae), and Celtis aspera (Celtidaceae, Table 1).

\section{Green River Basin}

The Green River Basin occupies southwestern Wyoming and portions of Colorado and Utah and includes both the Green River Basin proper and a series of subbasins including the Great Divide, Sand Wash, Vermilion Creek and Washakie Basins, (as well as a locality, the Bison Basin; Wilf 2000). To the south, the Green River Basin is separated from the Uinta Basin by the Uinta Mountains, and in the north from the Wind River Basin by the Wind River Mountains (Fig. 1). The western border of the Green River Basin is bounded by a complex series of imbricated thrust faults comprising the Sevier Belt. The easternmost of these thrust belts, the Hogsback Thrust, is the youngest and forms the boundary of both the Green River and Uinta Basins (DeCelles 1994). The Rock Springs Uplift segmented the Green River Basin proper from the Sand Wash Basin to the south, and the Washakie and Great Divide Basins to the north (Roehler 1993). Assemblages of sedimentary rocks spanning the late Cretaceous through the middle Eocene are found within the Green River Basin. The Paleocene is represented by fluvial 
Table 3. Almont and Beicegel Creek floras, Megafossil Occurrences. ${ }^{* *}-$ detailed published description; ${ }^{*}-$ short published description/photos; $\mathrm{AB}_{\text {- abstract; }}{ }^{\mathrm{PC}}$ - personal communication. Name is not always the same in Crane et al. (1990), but figure number indicates specimen.

\begin{tabular}{|c|c|c|c|c|c|}
\hline Family & Genus & Plant part & Almont & Beicegel Creek & References \\
\hline \multicolumn{6}{|l|}{ PTERIDOPHYTES } \\
\hline Blechnaceae & Woodwardia sp. & fronds & - & rare & ${ }^{*}$ Pigg et al. (2006), figs 4, 7 \\
\hline Ferns & Filicalean fern & frond, spores & - & rare & ${ }^{\mathrm{AB}}$ Matthews et al. (2006) \\
\hline Isoetaceae & Isoetes cf. horridus & megaspores & - & rare & ${ }^{\mathrm{AB}}$ Matthews et al. (2007) \\
\hline \multicolumn{6}{|l|}{ GYMNOSPERMS } \\
\hline Ginkgoaceae & Ginkgo adiantoides & leaves, seeds, ovulate stalks & abundant & common & ${ }^{*}$ Crane et al. (1990), fig. 2 \\
\hline Cupressaceae & cf. Parataxodium sp. & $\begin{array}{l}\text { leaves seeds pollen and seed cones } \\
\text { seeds }\end{array}$ & abundant & abundant & ${ }^{*}$ Crane et al. (1990), figs 3, 4 \\
\hline Cupressaceae & Metasequoia & seeds & rare & - & ${ }^{\mathrm{PC}}$ Manchester \\
\hline Pinaceae & cf. Pinus & ovule cone & - & rare & ${ }^{\mathrm{PC}}$ Manchester \\
\hline Taxaceae & Diploporus & seeds & occasional & occasional & ${ }^{*}$ Crane et al. (1990), fig. 25J \\
\hline Taxaceae & Torreya & seeds & rare & - & ${ }^{\mathrm{PC}}$ Manchester \\
\hline \multicolumn{6}{|l|}{ ANGIOSPERMS } \\
\hline Actinidiaceae & cf. Saurauia & seeds and fruits & occasional & $\begin{array}{l}\text { common } \\
\text { (seeds) }\end{array}$ & $\begin{array}{l}\text { *Crane et al. (1990), fig. 24A-E } \\
{ }^{\mathrm{AB}} \text { Pigg \& DeVore (2003) }\end{array}$ \\
\hline Araliaceae & Toricellia & fruit & rare & - & *Manchester et al. (2009) \\
\hline Betulaceae & $\begin{array}{l}\text { Palaeocarpinus } \\
\text { dakotensis }\end{array}$ & $\begin{array}{l}\text { infructesence fruits seeds pollen } \\
\text { catkins pollen }\end{array}$ & abundant & abundant & $\begin{array}{l}{ }^{*} \text { Crane } \text { et al. (1990), fig. 16, } 17 \\
* \text { Manchester } \text { et al. }(2004)\end{array}$ \\
\hline Betulaceae & Corylites sp. & leaves & abundant & abundant & $\begin{array}{l}\text { *Crane } \text { et al. (1990), fig. 18A, B } \\
{ }_{* * *} \text { Manchester } \text { et al. }(2004)\end{array}$ \\
\hline Cercidiphyllaceae & Nyssidium arcticum & fruits, seeds, leaves & occasional & - & *Crane et al. (1990), fig.10 \\
\hline Cornales & Amerisinia obtrullata & fruits, seeds & common & abundant & $\begin{array}{l}\text { * Crane } \text { et al. (1990), fig. } 24 \mathrm{~F}-\mathrm{H} \\
{ }^{* * *} \text { Manchester } \text { et al. }(1999)\end{array}$ \\
\hline Cornales & Beringiaphyllum & leaves & abundant & common & $\begin{array}{l}{ }^{*} \text { Crane } \text { et al. }(1990), \text { fig. } 30 \\
\text { Manchester } \text { et al. }(1999)\end{array}$ \\
\hline Cornales & cf. Cornus sp. & endocarps & rare & occasional & $\begin{array}{l}\text { *Crane et al. (1990), fig. 20G-I } \\
{ }^{*} \text { Xiang et al. (2003), fig. 3H }\end{array}$ \\
\hline Cornales & Davidia antiqua & infructescence fruit, leaves & common & & $\begin{array}{l}\text { *Crane et al. }(1990) \\
* \text { Manchester }(2002 \mathrm{a})\end{array}$ \\
\hline Cornales & cf. Diplopanax & endocarp & occasional & - & ${ }^{\mathrm{PC}}$ Manchester \\
\hline Hamamelidaceae & Hamawilsonia bogle & infructesence with seeds & occasional & - & $\begin{array}{l}{ }^{*} \text { Crane et al. }(1990), \text { fig. } 15 \\
{ }^{*} \text { Benedict } \text { et al. }(2008)\end{array}$ \\
\hline Hamamelidaceae & seeds & seeds & rare & & $\begin{array}{l}{ }^{*} \text { Crane et al. (1990), fig. } 27 \mathrm{E}-\mathrm{G} \\
{ }^{* *} \text { Benedict } \text { et al. }(2008)\end{array}$ \\
\hline Hamamelidaceae & $\begin{array}{l}\text { pollen catkins with in situ } \\
\text { pollen }\end{array}$ & pollen catkins, pollen & rare & & $\begin{array}{l}\text { * Crane et al. }(1900) \\
{ }^{*} \text { Benedict et al. }(2008)\end{array}$ \\
\hline Icacinaceae & Icacinicarya collinsonae & endocarp & 1 specimen & - & ${ }^{* *}$ Pigg et al. (2008b) \\
\hline Icacinaceae & Icacinicarya dictyota & endocarp & - & 1 specimen & ${ }^{* *}$ Pigg et al. $(2008 b)$ \\
\hline Icacinaceae & Palaeophytocrene & endocarps & rare & rare & ${ }^{*}$ Crane et al. (1990), fig. 22A-C \\
\hline Juglandaceae & Cyclocarya brownii & fruits, infructescence & common & common & $\begin{array}{l}\text { *** Manchester \& Dilcher (1982) } \\
{ }^{*} \text { Crane et al. }(1990 \text {, fig. } 8 \mathrm{C}, \mathrm{D}, \mathrm{F}, \\
\mathrm{G}{ }^{\mathrm{AB}} \text { Taylor }(2007)\end{array}$ \\
\hline Juglandaceae & & leaves & rare & - & ${ }^{*}$ Crane et al. (1990), fig. 19 \\
\hline Meliosmaceae & Meliosma rostellata & fruits & common & common & ${ }^{*}$ Crane et al. (1990), fig. 21 \\
\hline Menispermaceae & cf. Canticocculus & fruits & rare & - & ${ }^{*}$ Crane et al. (1990), fig. 5 \\
\hline Menispermaceae & cf. Tinomiscium & fruit & rare & - & ${ }^{\mathrm{PC}}$ Manchester \\
\hline Myrtaceae & Paleomyrtinea & fruits and seeds & occasional & common & $\begin{array}{l}{ }^{*} \text { Crane } \text { et al. }(1990) \text {, fig. } 20 \mathrm{~A}-\mathrm{E} \\
{ }^{* *} \text { Pigg } \text { et al. }(1993) \text {, figs } 18-22,24\end{array}$ \\
\hline
\end{tabular}


Table 3. continued

\begin{tabular}{|c|c|c|c|c|c|}
\hline Family & Genus & Plant part & Almont & Beicegel Creek & References \\
\hline Nymphaeaceae & Susiea newsalemae & seeds & rare & rare & ${ }^{* * *}$ Taylor et al. (2006) \\
\hline Nymphaeaceae & Nuphar wutuensis & seeds & 1 specimen & 1 specimen & ${ }^{* *}$ Chen et al. $(2005)$ \\
\hline Ochnaceae & Ochna sp. & & rare & rare & $\begin{array}{l}\text { *Crane et al. (1990), fig. 26A-C } \\
{ }^{\mathrm{AB}} \text { Pigg et al. }(2005)\end{array}$ \\
\hline Platanaceae & Macginicarpa & infructesence & rare & - & ${ }^{\mathrm{PC}}$ Manchester \\
\hline Platanaceae & unnamed & pollen catkin & rare & - & *Crane et al. (1990) \\
\hline Platanaceae & Macginitiea & leaves & occasional & occasional & ${ }^{\mathrm{PC}}$ Manchester \\
\hline Platanaceae & leaf types $a, b, c$ & leaf & rare & - & ${ }^{*}$ Crane et al. (1990), fig. 11 \\
\hline Polygalaceae & Paleosecuridaca curtisii & fruit & common & rare & $\begin{array}{l}\text { *Crane et al. }(1990), \text { fig. } 23 \mathrm{~A}-\mathrm{C} \\
{ }^{* *} \text { Pigg et al. }(2008 \mathrm{a})\end{array}$ \\
\hline Ranunculaceae & Paleoactaea nageli & fruit and seeds & rare & rare & $\begin{array}{l}\text { *Crane et al. (1990), fig. 25D-F } \\
{ }^{* *} \text { Pigg \& DeVore (2005) }\end{array}$ \\
\hline Sapindaceae & cf. Acer & fruit & common & common & $\begin{array}{l}\text { *Crane et al. (1990), fig. 22B-D } \\
{ }^{\mathrm{AB}} \text { Kittle } \text { et al. }(2005)\end{array}$ \\
\hline Sapindaceae & Aesculus & leaf & rare & - & ${ }^{* * *}$ Manchester (2000) \\
\hline Sapindaceae & cf. Sapindus & fruit & rare & - & ${ }^{\mathrm{PC}}$ Manchester \\
\hline Trochodendraceae & Nordenskioldia borealis & fruit & common & common & $\begin{array}{l}\text { *Crane et al. }(1990) \\
* \text { Crane et al. }(1991)\end{array}$ \\
\hline Trochodendraceae & Zizyphoides flabella & leaf & abundant & common & $\begin{array}{l}{ }^{*} \text { Crane et al. }(1990) \\
{ }^{* *} \text { Crane } \text { et al. }(1991)\end{array}$ \\
\hline Vitaceae & Ampelocissus & leaf & rare & rare & ${ }^{\mathrm{PC}}$ Manchester \\
\hline Zingiberalaes & Spirematospermum & embryo, seed & occasional & abundant & $\begin{array}{l}\text { *Crane et al. (1990), fig. 26D-F } \\
{ }^{\mathrm{AB}} \text { Benedict } \text { et al. (2007) }\end{array}$ \\
\hline Incertae sedis & Averrhoites affinis & leaf & occasional & occasional & ${ }^{*}$ Crane et al. (1990), fig. 31 \\
\hline Incertae sedis & Porosia verrucosa & seed & occasional & occasional & $\begin{array}{l}\text { *Crane et al. (1990), fig. 29C, D } \\
{ }^{* *} \text { Manchester (2002b) }\end{array}$ \\
\hline Incertae sedis & monocot & leaves, rhizomes & rare & abundant & $\begin{array}{l}\text { *Crane et al. (1990), fig. 29a, b } \\
{ }^{\mathrm{AB}} \text { DeVore } \text { et al. }(2004)\end{array}$ \\
\hline Incertae sedis & fruits, seeds, leaves & fruits, seeds, leaves & & & *Crane et al. (1990) \\
\hline
\end{tabular}

deposits assignable to the Fort Union Formation while the Wasatch Formation, also reflecting a fluvial deposition, extends from the early to middle Eocene and interfingers with the lacustrine, early and middle Eocene Green River Formation (Roehler 1985, 1993; Wilf 2000).

To assess climate changes across the Paleocene-Eocene boundary, Wilf (2000) sampled seven floral assemblages spanning the boundary. The first and lowermost assemblage is from the Bison Basin locality in the Fort Union Formation in the Great Divide Basin, and is of Tiffanian age (Gemmill \& K. Johnson 1997). The second assemblages (2 and 2a of Wilf 2000) are the Clarkforkian and Big Multi Quarry floras, of early Clarkforkian age, which span the upper Paleocene Fort Union Formation in southern Wyoming and provide its youngest records. The third assemblage, from the Wasatch Main Body, generally has a sandy lithology with numerous oxidized beds and occasional weathered, carbonaceous deposits. Plant material is both infrequent and low in diversity. Further upsection, the fourth assemblage is a tabular carbonaceous shale unit from the Ramsey Ranch Member of the Wasatch Formation above the Latham 4 coal, which yields slightly better preserved material. The fifth is the Sourdough assemblage, which comprises a set of sites, located just upsection from the Latham 4 coal in the uppermost Ramsey Ranch Member of the Wasatch Formation and associated with the Sourdough 2 coal zone. Floristically, the Sourdough assemblage is very similar to the Elk Creek section in the Bighorn Basin (Davies-Vollum \& Wing 1998) and provides some interbasinal comparison between the Bighorn and Green River Basins. The sixth assemblage is the Niland Tongue from the last fluvial unit sampled in the early Eocene, and the seventh and last assemblage is the Little Mountain assemblage of early Bridgerian age from the lacustrine Green River Formation.

Wilf's (2000) detailed treatment of these data using leaf-margin and leaf area analyses, as well as assessment of the climatic tolerances of nearest living relatives for 
paleoclimate analysis, provided a rich record of climate change between the Paleocene and Eocene in the Green River Basin. In conjunction with analyses of leaf floras, Wilf estimated numbers of "species" based on counts of both formally described species and leaf morphotypes to track changes in floral diversity. Two floral turnovers, the first representing the Clarkforkian-Wasatchian warming and the second associated with the WasatchianBridgerian drying interval, are documented (Table 2). More than $80 \%$ of the "species" were affected by these two events.

The studies described above represent an important initial step in understanding the interrelationships between regional and global signals. Because people want to use these results to correlate global climate events, it is important to tease out the local and regional influences. Clearly, integrative studies interweaving details of the tectonic events influencing the development of these basins, as well as patterns of paleodrainage and depositional systems, enhance the ability to unravel local, regional and global signals present in the multitude of proxy data sets based on paleontological sources.

\section{Williston Basin}

The largest, easternmost of the basins associated with stratigraphic sequences spanning the Paleocene-Eocene boundary is the Williston Basin which covers parts of North Dakota, South Dakota, Montana in the USA and southern portions of the Canadian provinces of Manitoba and Saskatchewan (Fig. 1).

Today the Williston Basin is actually two basins. The Williston Basin proper is found to the NW with a second arm of the complex called the Powder River Basin. The two basins appear to meet at the Miles City Arch with the Williston Basin extending to the Black Hills and the Powder River Basin being roughly flanked on its east and west margins by the Black Hills and Bighorn Mountains. The present paper will focus on the depositional environments of the following floras of the Williston Basin: Ravenscrag, Almont, Beicegel Creek, Wannagan Creek, and Golden Valley.

The Williston Basin has a long history and numerous processes have influenced its formation, and there have been several interpretations regarding its development. One hypothesis is that the basin formed as a tensional response to shearing between two lineaments during the $\mathrm{Pa}-$ leozoic (Gerthard et al. 1982). The folding and faulting within the Williston Basin has been attributed to both movement along basement blocks and as a response to subsidence. Compared with other basins in the Great Plains and Rockies, the degree of faulting is slight and seismic surveys are necessary to document the nature and extent of these faults. In particular, the faults associated with the Cedar Creek, Nesson, and Heart River Anticlines, have extremely steep dips and have experienced episodes of near vertical displacement. Some synclinal formations within the basin are attributed to collapse after the dissolution of Devonian age salt deposits.

The Williston Basin may appear to have a simple, layered stratigraphy, but the interplay of the tectonics and shifts in paleodrainage, clearly paint a more complex picture as illustrated by a recent study (Belt et al. 2004) on the unconformities and age relationships of the Tongue River and older members of the Fort Union Formation. Similar studies on the Sentinel Butte Member have not been undertaken.

Ravenscrag flora. - Another region, flanking the northern rim of the Williston Basin, has yielded fossil plant assemblages. The Paleocene Ravenscrag Formation of southwestern Saskatchewan does not extend stratigraphically across the Paleocene-Eocene boundary as is the case with the Golden Valley Formation from the Williston Basin of North Dakota (see below). However, the Ravenscrag Formation can be correlated with the Cretaceous (Maastrichtian) Hell Creek Formation up through most of the Bullion Creek Formation of North Dakota and is interpreted as Puercan to Torrejonian in age (McIver \& Basinger 1993).

At the end of the Cretaceous, cratonic subsidence, in concert with subsidence caused by salt dissolution of the Devonian Prairie Evaporate (Broughton 1979, Frank \& Bend 2004), caused deposition of thin (0.5-1.0 m) coal deposits with thicker beds (avg. $3.2 \mathrm{~m}$ ) being deposited when cratonic and salt dissolution subsidence decreased during the Paleocene. Regional and local subsidence influenced sedimentation and makes correlation within and between the regional units difficult (Frank \& Bend 2004).

The Ravenscrag Formation consists of lignite-bearing clay, silt and sand beds overlying the latest Cretaceous (Maastrichtian) Frenchman Formation. The beds assigned to the Ravenscrag Formation were deposited as an eastward-thickening wedge representing a low-energy fluvial-alluvial plain depositional system [S.G.S. (Saskatchewan Geological Survey) 1994, Frank \& Bend 2004]. The site is interpreted as an alluvial plain with meandering streams, ponds, swamps and lowland forests.

The Ravenscrag flora represents a polar broadleaf temperate forest. Floral elements include woody dicots of Cercidiphyllaceae, Cornophyllum and a compound leaf type Platanaceae (Platanites canadensis) similar to those found at Mull, Scotland (Crane et al. 1988; Kvaček et al. 2001). Several filicalean ferns, including Woodwardia gravida, are present, and the common conifers include the cupressaceous genera Mesocyparis and Glyptostrobus while Fokienia and Elatocladus are present but uncommon. The most common type of fossil at this locality is the 
dicot leaves that were assigned to Dicotylophyllum anomalum by McIver \& Basinger (1993). The leaves are now considered assignable to Browniea (Nyssaceae: see Manchester \& Hickey 2007). Interestingly, some elements that are often characteristic of Paleocene floras (e.g., Ginkgo, Glyptostrobus) are relatively rare here (McIver \& Basinger 1993) or even lacking (Betulaceae). There is a diversity of aquatic forms, which include Isoetes horridus, two species of Azolla, the Trapa-like genus Trapago, the Nelumbo-like Nelumbago, and several rosette-forming moncots described as Pistia and Spirodela (now Limnobiophyllum, Stockey et al. 1997).

Studies of the Souris Lignite from the Ravenscrag (Frank \& Bend 2004) indicate that transitional fern-dominated and Taxodium-dominated stable environments coexisted and suggest the Okefenokee Swamp (Georgia, USA) as a possible modern analogue. The Okefenokee also has been proposed as a modern analogue to the Tertiary peatforming environments of the northern Great Plains (Rich 1979).

Wannagan Creek. - The Wannagan Creek site is well known for its rich assemblage of vertebrate faunas (predominately champsosaurs, crocodilians, turtles) but also contains beds bearing less studied plant material (Erickson 1991). The portion of the Bullion Creek Formation section at Wannagan Creek that has been the focal point for paleontological investigation lies $19.8 \mathrm{~m}$ above the contact with the underlying Sentinel Butte Formation (Melchior \& Hall 1983).

Jacob (1972) and particularly Melchior \& Hall (1983) have interpreted the depositional environment as representing a floodplain based on three distinct beds. The first is primarily fluvial and fines upwards from a course silt to a silty clay and contains remains of an aquatic plant community consisting of fossils identified as Cabomba, Equisetum, Nelumbium, Sparganium, and in situ corms assignable to Isoetites horridus. The second bed, a lignitic black shale rich in organics, is interpreted as an isolated channel segment and contains large branches and tree trunks, but identifiable plant megafossils are rare until the last, upper $5 \mathrm{~cm}$ of the bed, where leaves become abundant. It is in bed 2 that the articulated fossils of vertebrates are found. The third bed is a massive unit consisting of coarse silt and fining upward to clays. This third bed is interpreted as a flood surge or crevasse splay from an adjacent channel (Melchior \& Hall 1983). Although several studies have focused on the palynomorphs, particularly the megaspores (e.g., Melchior \& Hall 1983), the megaflora is not comprehensively illustrated and identifications of megafossil elements need to be verified.

Almont and Beicegel Creekfloras. - The Almont flora was first described by Crane et al. (1990) and is unusual since the plants are preserved both morphologically and anatomically (Table 3). The original site, located near the center of North Dakota, outcrops at the very surface and is impossible to place within a stratigraphic context. Based on the floral assemblage, the site was assigned to the late Paleocene Sentinel Butte Formation. The plant material is preserved in siliceous shale units that appear to represent clay lenses deposited in abandoned channels and then enriched by silica and iron-rich solutions. Whether the Almont site represents a single channel, or a set of small interfingered channels, is uncertain. However, it does appear that the fossil-bearing sedimentary units are discontinuous at the Almont site.

In 1999, a new site was found in the Beicegel Creek area of McKenzie County, in western North Dakota, with the siliceous shales found in place within a friable, gray sandstone (Table 3). Material collected from the Beicegel Creek region can be studied both by sectioning and SEM, (as can the Almont material), as well as by the cellulose acetate peel method (Joy et al. 1956, Basinger \& Rothwell 1977). The amount of carbon preservation is exquisite in comparison to other silicrete beds found in the Sentinel Butte and Golden Valley Formations. This flora is much more diverse than the similarly preserved permineralizations described by Ting (1972) from younger strata associated with the Golden Valley flora. The geochemical circumstance permitting this preservation, combined with the high number of taxa shared by both the Almont and Beicegel Creek floras, in no way can be explained as being part of a single, widespread bed, but rather, represents deposition within the same meandering fluvial system (DeVore, personal observation).

The Sentinel Butte Formation has been characterized by the dominance of illite and montmorillonite clays, its olive-green color, orange-stained zones with nodules of siderite, "bentonite" layers, and the abundance of petrified conifer wood (Hickey 1977). Fischer (1953) observed petrified stumps below the Sentinel Butte-Golden Valley contact and Hickey (1977) noted a zone of stumps below the contact in areas including the Crooked Creek escarpment in southwestern Dunn County and eastern Stark County. During fieldwork in McKenzie County, the present authors have noted a zone of taxodiaceous conifer stumps present in some areas of the contact, but there also appears to be other zones of stumps present below the contact. Along with the lignite and petrified stump zones are plant-bearing beds that appear to be associated with channel fills (DeVore, personal observ.).

Golden Valley flora. - In North Dakota, the Sentinel Butte Formation is, in general, regionally conformably overlain by the Golden Valley Formation. In western North Dakota, these formations outcrop discontinuously on isolated but- 
tes and are best exposed in the Little Badlands. Generally, the sequences of the Golden Valley Formation consist of paulstrine to fluvio-deltaic sequences and are divided into two members. The lower Bear Den Member is dominated by kaolinitic claystones and siltstones. The upper Camels Butte Member, in contrast, contains lenses of micaceous, crossbedded sandstones separated by finer-grained beds (Hickey 1977). Both members represent fluvial deposits, and occasionally, both the Bear Den and Camels Butte Members downcut into the underlying Sentinel Butte Formation. The current placement of the Paleocene-Eocene boundary is within the Bear Den (Clechenko et al. 2007). Hickey (1977) found 41 Golden Valley Formation localities containing fossil plant beds. Twenty-seven of these in the Bear Den Member were found in the lower 9.1 meters of the unit and would therefore, represent the latest Paleocene flora in the Williston Basin.

Carbon isotope values of bulk organic matter and palynostratigraphy were studied within the Golden Valley Formation to try to identify the PETM (Harrington et al. 2005, Clechenko et al. 2007). The "orange zone" identified within the Bear Den Member was interpreted as representing an episode of intense pedogenesis at $c a 55$ Ma based on the high abundances of iron-stained kaolinite, poor organic carbon preservation and the presence of features roughly equivalent to those found in modern laterites.

The Golden Valley flora was described from a series of approximately 70 localities in 6 transects across North Dakota (Hickey 1977). Of 82 total taxa, 52 are present at Bear Den and 42 at Camels Butte. Sixteen taxa are shared, including, most notably: Equisetum, Glyptostrobus, Metasequoia, Porosia, Davidia (listed as "Viburnum" antiquum, Manchester 2002a), Cercidiphyllum, Cornus, Aesculus (listed as Carya antiquua; see Manchester 2001), Averhoites, Meliosma, Chaetoptelea, and "Ampelopsis", with 36 taxa unique to Bear Den and 24 to Camels Butte (Hickey 1977). Notable genera at Bear Den but not Camels Butte, include: the filicalean ferns Osmunda and Woodwardia, Pinus prergrimus, Acer, Beringiaphyllum (listed as Viburnum cupanoides, see Manchester et al. 1999), Zizyphoides (listed as Cocculus flabella, Crane et al. 1991). Camels Butte hosts Isoetes horridus, the small aquatic lycopod, and the aquatic floating heterosporous water fern Salvinia, leaves assigned to Betula hesterena (probably closely related to Corylites leaves of Palaeocarpinus). The Golden Valley flora apparently lacks Ginkgo.

\section{Alberta Basin}

Genesee, Munce's Hill, and Joffre Bridge floras. - Paleocene aged floras have also been recovered from the Paskapoo Formation of south-central Alberta. The Paskapoo
Formation represents deposition by rivers that flow eastward from the cordillera to the Alberta Basin (Fig. 1). The basin parallels the cordillera and extends eastward into south-central Alberta for more than $600 \mathrm{~km}$ (Demchuk et al. 1991, Hoffman \& Stockey 1999). The Paskapoo Formation can be correlated with the upper part of the Ravenscrag Formation (Demchuk et al. 1991).

The Paskapoo Formation yields three main productive sites at Genesee, Munce's Hill and the Joffre Bridge Roadcut locality (Hoffman 2002). Of these, Genesee is the earliest studied site, and of relatively low diversity (19 taxa), with several significant elements typical of a polar deciduous flora (Chandrasekharam 1974). The flora is dominated by Metasequoia (36\%) and Cercidiphyllaceae (around 33\%), with additional representatives of Glyptostrobus, Fokienia, Taxodium, Azolla, Platanus, Nordenskioldia, a moss, and several ferns. This site boasts the only known fossil record of the ophioglossalean fern Botrychium, which has been reconstructed as a "whole plant" that bears a remarkable resemblance to its extant relative (Rothwell \& Stockey 1989). Two typical taxa of the late Paleocene, Betulaceae and Ginkgo, apparently are lacking.

The Munce's Hill locality contains a relatively low diversity assemblage ( 9 taxa) that has been interpreted as a wetland forest community (Stockey et al. 2006). This flora is dominated by Metasequoia and the fern Onoclea. Metasequoia foxii plants, including their seedlings, are known from both Munce's Hill, and a second nearby and contemporaneous locality at Guo Mine. From these sites Metasequoia foxii has been reassembled as a "whole plant" (Falder et al. 1999, Stockey et al. 2001). Although taxodiaceous conifers are very common components of Paleogene floras, it is rare to find all of the separate organs together in the same horizon and in attachment to one another. Metasequoia foxii can be compared with Metasequoia milleri, another whole Metasequoia plant that is known from the Eocene Princeton Chert (Basinger 1981, 1984; Rothwell \& Basinger 1979).

Another whole plant reconstruction from Munce's Hill is that of the fern Onoclea (Rothwell \& Stockey 1991). The authors placed this fossil fern into the modern species $O$. sensibilis because it is essentially identical in sporophyte and spore morphology to the extant plants. Rhizomes in growth position, bearing attached vegetative and fertile fronds, were uncovered carefully in the field and photographed in situ to demonstrate their morphology and plant habit. This was necessary because the beds have been severely affected by post-depositional cleavage perpendicular to the bedding plane, such that larger slabs bearing more complete fronds could not be recovered. Other taxa from Munce's Hill include the thelypterid fern Speirsiopteris orbiculata (Stockey et al. 2006); Palaeocarpinus joffrensis (Sun \& Stockey 1992); 
Equisetum sp. (Vavrek 2002); a possible bryophyte; stem remains of Joffrea, and Aphananthe, of possible ulmaceous affinities; and the foliage type Wardiaphyllum (Stockey et al. 2006).

Hoffman \& Stockey (1999) studied the depositional environment of the Joffre Bridge Roadcut locality, and recognized five depositional units: 1) floodplain; 2) fluvial channel; 3) abandoned channel; 4) swamp, and 5) crevasse splay. The floodplain deposits, which are capped by a paleosol with vertebrate remains, lack identifiable plant remains. Fluvial and abandoned channel sediments overlay the paleosol and contain remains of riparian trees (e.g., Platanaceae, Joffrea). The fourth depositional unit, a carbonaceous mudstone, representing a swamp facies, overlies the channel sediments and includes taxodiaceous conifers and riparian trees. The mudstone units on top of the swamp facies also contain taxodiaceous conifers and riparian trees, but also have preserved a record of the aquatic and understory vegetation. Hoffman \& Stockey (1999) interpret these as reflecting deposition in the distal margin of a crevasse splay. Units above the mudstone coarsen upward and are nearly devoid of fossils except for a zone of articulated fish skeletons. The sequences reflecting channel-abandonment, the swamp horizon, and the base of the crevasse splay have yielded the best assemblages of plant fossils.

The Joffre Bridge Roadcut locality is the most floristically diverse of the Paskapoo Formation floras with over 28 species named (Hoffman 2002). The dominant plant in this flora is by far Joffrea speirsae, an extinct member of the Cercidiphyllaceae. Joffrea has been reconstructed as a "whole plant", based on interconnected organs including inflorescences, infructesences, seeds, pollen and leaves, as well as young seedlings (Stockey \& Crane 1983; Crane \& Stockey 1985, 1986a). A second whole plant reconstruction is of the "Joffre Plane Tree", a platanaceous plant based on leaves, pistillate inflorescences and infructescences (Macginicarpa manchesteri), staminate inflorescences, dispersed stamen clusters and in situ pollen (Platananthus speirsae), and young seedlings (Pigg \& Stockey 1991). Other important taxa are the conifers Glyptostrobus and Metasequoia and leaves of Beringiaphyllum (Cornales). Other taxa include Equisetum, Osmunda, Chaetoptelea, Averrhoites, and Acer-like samaras.

Aquatic ferns (e.g., Azolla), and monocots (Limnobiophyllum, Pistia) are prominent members of the floating vegetation. Other aquatic plants include the liverwort Ricciopsis. Structures referred to as "unidentified sheathing structures" are very similar to monocot "leaf rings" seen in abundance at Beicegel Creek (DeVore et al. 2004) and commonly throughout Paleocene strata. These leaf rings and associated leaves resemble the monocot leaf type Zingiberopsis (Hickey \& Peterson 1978) whose affinities are unknown.

\section{Case histories of Late Paleocene to Early Eocene plants}

\section{Filicalean ferns}

Generally, filicalean ferns have not been studied in detail in late Paleocene to early Eocene localities of western North America. This is in part because they are not typically prominent components of the floras, and also because of the strong bias toward collecting and describing dicot leaves. Even with this sampling bias, however, there are several notable exceptions that may be related directly to the paleoecology of particular environments where ferns were prominent. Two examples are Onoclea sensibilis at Munce's Hill, and the abundance of the fern association of Woodwardia gravida, Osmunda and Onoclea in the Ravenscrag assemblage. Paleocene Onoclea sensibilis occupies essentially the same niche at Munce's Hill, a wetland forest community, as it does today (Rothwell \& Stockey 1991). In the Eocene, ferns are also locally important in several sites, including some of the Golden Valley floras.

In contrast is the surprising absence of ferns at the Almont locality and their relatively rare occurrence at Beicegel Creek where their record consists of fragmentary vegetative and fertile pinnules and anatomically preserved rhizomes (Pigg et al. 2006). To date, we have not been able to recognize whether this is preservational bias, or if indeed the ferns were not a major component of these floras. One potential explanation for this rarity of fern megafossils has to do with ground water levels and fluvial activity. This suggestion arises from consideration of the cycles documented for the Souris seam of the Ravenscrag Formation (Frank \& Bend 2004). As noted above, the localities with significant records of ferns are found either in the Alberta Basin or northern edge of the Williston Basin. In regards to the Williston Basin in particular, the southern and western portions of the Basin are more strongly influenced by uplift events while more subsidence, in particular due to salt dissolution, is prevalent in the northern, Canadian region of the Basin. Higher-energy fluvial systems would, therefore probably prevail in the south and less energetic systems would be present in the Canadian portion of the Williston Basin. The cycles described by Frank \& Bend (2004) occur in a low-energy fluvial plain. Of the six stages they documented there is a point during the second cycle where ferns persist as groundwater levels rise. However, Frank \& Bend (2004) noticed, based on petrographic analysis of samples, an increase in clastics, indicating the migration of an active river channel towards the fern-dominated mire. Fluvial activity escalated to the point that detrital clastic material choked the fern-rich mire associated with peat formation. Possibly the higher energy regimes present in the Almont and Beicegel Creek systems exhibit a different cycle representative of higher energy river systems. 


\section{Azolla, Salvinia and other aquatics}

The aquatic ferns Azolla and Salvinia are excellent indicators of still-water habitats and serve to document the presence of lacustrine environments. In general, there seems to be a replacement of Azolla by Salvinia across the Paleocene to Eocene transition in the Great Plains and Rocky Mountain regions. Azolla then reappears in the Eocene of the Bighorn Basin after the appearance of Salvinia (Table 4). Later in the Eocene, both taxa occur in the lake deposits of the Okanogan Highlands, where Azolla is especially common in some horizons (e.g., Arnold 1955, DeVore \& Pigg 2008).

Several of the localities have diverse aquatic assemblages that include not only heterosporous water ferns but also Isoetes, monocots assignable to Araceae and Lemnaceae, and forms close to Trapa. At Ravenscrag, all of these components occur, and at Joffre Bridge we see $A z$ olla, Spirodela and Limnobiophyllum, and possibly Isoetes (Table 4). Isoetes also occurs in the Golden Valley, Beicegel Creek and Wannagan Creek floras but not at Almont. Interestingly, although we see nymphaeceous seeds at Almont (Nuphar and Susiea, a form in the Eurale lineage; Taylor et al. 2006), none of the other aquatics are present. The enigmatic Porosia (Manchester 2002b) is known in the Williston Basin and lower sections of the Bighorn Basin. Typha apparently comes in during the Eocene.

Studies of the Paleocene-Eocene transition in North America have largely focused on terrestrial ecosystems and their response to climate change. To date, we could not identify a study focused on the response of freshwater aquatic ecosystems across the Paleocene-Eocene transition. Such a study would require identifying stratigraphic sequences with facies containing assemblages of aquatics that have not been transported a significant distance from the site of deposition.

\section{Ginkgo}

Ginkgo is one of the most common genera found in the Almont flora and in certain sites within the Beicegel Creek locality and Wannagan Creek. It is rare in the Ravenscrag flora and at Joffre Bridge, and apparently absent at the Golden Valley and the Green River sites (Table 4). By the Eocene, the genus disappears in the Williston Basin, yet persists in the Bighorn Basin, and still remains present in northwestern North America into the Miocene. The record of Ginkgo at Almont is particularly interesting because in addition to well-preserved leaves, often with cuticle, numerous seeds and reproductive stalks also have been found (Crane et al. 1990). In some cases the fleshy sarcotesta of the seed is preserved. Even though Ginkgo leaves are rela- tively common in many younger western Tertiary floras, the occurrence of seeds is rare.

Extant Ginkgo trees only become reproductively mature and capable of bearing seeds at 20-30 years of age (He et al. 1997). Because no natural populations of the genus are known, it is not clear what the extant plant's natural habitat would be, however, in the Cretaceous and Tertiary record, fossil Ginkgo is typically found in depositional environments that indicate open canopy forests in disturbed habitats, along stream margins and the distal sides of levees. There they commonly co-occur with riparian trees such as Cercidiphyllum and Platanus (Royer et al. 2003). At Almont Ginkgo co-occurs with these taxa, along with other genera, and the depositional environment is inferred to be a meandering fluvial system. What is unusual is the occurrence of numerous Ginkgo seeds and reproductive stalks. If fossil Ginkgos shared the phenology of today's forms, this suggests that the ginkgos at Almont were mature forest trees. Why Ginkgo seeds are well preserved at Almont and not at similar localities, is unclear.

\section{Taxodiaceous conifers}

Although taxodiaceous conifers (Taxodium, Parataxodium, Metasequoia and Glyptostrobus) are common components of the Paleocene to Early Eocene floras of western North America, their actual patterns of distribution are interesting. Taxodium and Parataxodium are present at Genesee, early parts of the Williston Basin (Almont, Beicegel Creek and Wannagan Creek) and early in the Bighorn Basin. Metasequoia is common in most areas, except for Almont and Beicegel Creek, and is only in the early Green River floras. This genus is particularly significant at the Munce's Hill locality in Alberta, where a whole plant reconstruction of Metasequoia foxii includes different developmental stages of seedlings (Falder et al. 1999, Stockey et al. 2001). Glyptostrobus is widespread throughout the Bighorn Basin and appears sporadically in other sites, at Ravenscrag, in Alberta, at both Golden Valley sites and Wannagan Creek, and rarely at Almont. Hoffman \& Stockey (1999) note that at Joffre Bridge these conifers dominate the "mollusc layer" which is interpreted as a swamp horizon. Today, Taxodium is limited in its natural distribution to the southeastern United States, while Metasequoia and Glyptostrobus are Asian. It seems that in the examined floras Taxodium-like plant remains are less common, except at Almont, providing another example of Almont's unusual flora in comparison to other Paleocene sites. We note that pines (not recorded in Table 4) are quite rare in the late Paleocene and early Eocene of the Great Plains and Rocky Mountains. 
Table 4. Qualitative distribution of important Paleocene and Early-Middle Eocene taxa in western North America. Older names are included in parentheses after current identifications. Localities and floras: Bighorn Basin (BH; ages a-j); Green River (GR: ages a-g); in the Williston Basin: Almont (al), Beicegel Creek (bc), Golden Valley (gv), Bear Den Member (bd), Camels Butte Member (cb), Wannagan Creek (wc), Ravenscrag (rv); in the Alberta Ba$\sin (\mathrm{AB})$ : Genesee (ge), Joffre Bridge (jb), Munce's Hill (mh). + present, - absent, C - common, R - rare, VC - very common, * most common taxon at locality. Locality details for Green River and Bighorn Basins are detailed in Table 5. Based on literature cited in the text and personal observations.

\begin{tabular}{|c|c|c|c|c|c|c|c|c|c|c|c|}
\hline Taxon & $\begin{array}{c}\mathrm{BH} \\
\text { abcdefghij }\end{array}$ & $\begin{array}{c}\text { GR } \\
\text { abcdefg }\end{array}$ & $\begin{array}{c}\text { WB } \\
\text { al }\end{array}$ & $\begin{array}{l}\text { WB } \\
\mathrm{bc}\end{array}$ & $\begin{array}{c}\text { WB } \\
\text { gv(bd) }\end{array}$ & $\begin{array}{c}\text { WB } \\
\mathrm{gv}(\mathrm{cb})\end{array}$ & $\begin{array}{l}\text { WB } \\
\text { wc }\end{array}$ & $\begin{array}{l}\text { WB } \\
\text { rv }\end{array}$ & $\begin{array}{l}\mathrm{AB} \\
\mathrm{ge}\end{array}$ & $\begin{array}{l}\mathrm{AB} \\
\mathrm{mh}\end{array}$ & $\begin{array}{c}\mathrm{AB} \\
\mathrm{jb}\end{array}$ \\
\hline \multicolumn{12}{|l|}{ Pteridophytes } \\
\hline Azolla & hij & - & - & - & - & - & + & + & + & - & + \\
\hline Salvinia & fghij & def & - & - & - & - & - & - & - & - & - \\
\hline Lygodium & $\mathrm{fj}$ & def & - & - & - & + & - & - & - & - & - \\
\hline Onoclea & $\mathrm{a}$ & - & - & - & + & + & - & + & - & + & - \\
\hline Osmunda macrophylla & - & $\mathrm{a}$ & - & - & + & - & - & $+\mathrm{R}$ & - & - & - \\
\hline Woodwardia gravida & defj & be & - & + & + & - & - & $+\mathrm{C}$ & - & - & - \\
\hline Equisetum & abdfgj & abefg & - & - & + & - & + & + & - & + & $+\mathrm{R}$ \\
\hline Isoetites horridus & $\mathrm{e}$ & - & - & + & - & + & + & + & - & - & + \\
\hline \multicolumn{12}{|l|}{ Gymnosperms } \\
\hline Ginkgo & abefgh & - & $+\mathrm{C}$ & $+\mathrm{C}$ & - & - & + & $+\mathrm{R}$ & - & - & $+\mathrm{R}$ \\
\hline Zamia coloradensis & $\mathrm{d}$ & - & - & - & - & - & - & - & - & - & - \\
\hline Fokienia & abde & - & - & - & - & - & - & $+\mathrm{R}$ & + & - & - \\
\hline Glyptostrobus & abcdefgj & be & $+\mathrm{R}$ & - & + & + & + & + & + & - & + \\
\hline Metasequoia & abcdefgh & abd & + & - & + & + & - & $+\mathrm{R}$ & + & $+^{*}$ & + \\
\hline Taxodium /Parataxodium & $\mathrm{ab}$ & $?$ & + & + & - & - & + & - & + & - & - \\
\hline \multicolumn{12}{|l|}{ Angiosperms } \\
\hline \multicolumn{12}{|l|}{ Betulaceae } \\
\hline Betula/Corylites & de & $\mathrm{abc}$ & $+\mathrm{VC}$ & $+\mathrm{VC}$ & - & + & - & - & - & + & - \\
\hline Palaeocarpinus & + & $\mathrm{ab}$ & + & + & - & - & - & - & - & + & - \\
\hline \multicolumn{12}{|l|}{ Celtidaceae } \\
\hline Celtis aspera (Viburnum asperum) & acde & $\mathrm{ab}$ & - & - & - & - & + & - & - & - & - \\
\hline \multicolumn{12}{|l|}{ Cercidiphyllaceae } \\
\hline Cercidiphyllum/Joffrea & abcdefghj & $\mathrm{ab}$ & + & - & + & + & + & + & + & $+\mathrm{R}$ & $+^{*}$ \\
\hline Nyssidium & - & $?$ & + & - & + & - & - & + & - & - & + \\
\hline \multicolumn{12}{|l|}{ Cornaceae } \\
\hline Cornus & def & - & + & + & + & + & - & + & - & - & - \\
\hline \multicolumn{12}{|l|}{ Lemnaceae } \\
\hline Limnobiophyllum (Spirodela) & hi & - & - & - & - & - & - & + & - & - & + \\
\hline \multicolumn{12}{|l|}{ Nyssaceae } \\
\hline Browniea (Dicotylophyllum anomalum) & $\mathrm{a}$ & $+?$ & $+\mathrm{R}$ & - & + & + & + & $+*$ & $?$ & $?$ & $?$ \\
\hline Davidia (Viburnum antiquum) & $\mathrm{cd}$ & $\mathrm{ab}$ & + & + & + & + & + & - & - & - & - \\
\hline Beringiaphyllum (Viburnum cupanioides) & bcde & $\mathrm{ab}$ & + & + & + & - & + & - & - & - & + \\
\hline \multicolumn{12}{|l|}{ Platanaceae } \\
\hline Platanus raynoldsii & abcdefghj & ag & - & - & - & - & + & - & - & - & - \\
\hline \multicolumn{12}{|l|}{ Sapindaceae } \\
\hline Aesculus hickeyi (Carya antiquorum) & abcdef & abc & + & - & $*$ & - & + & - & - & - & - \\
\hline \multicolumn{12}{|l|}{ Tochodendraceae } \\
\hline Zizyphoides (Cocculus flabella) & $\mathrm{a}$ & $?$ & $+\mathrm{C}$ & $+\mathrm{VC}$ & + & + & + & - & - & - & - \\
\hline \multicolumn{12}{|l|}{ Incertae sedis } \\
\hline Averrhoites & abcdefghj & bcdefg & + & - & + & + & - & + & - & - & + \\
\hline Porosia & bcde & $\mathrm{b}$ & + & + & + & - & - & + & - & - & - \\
\hline Zingiberopsis isonervosa & deghij & bcdef & $+\mathrm{R}$ & + & - & + & + & + & - & - & + \\
\hline
\end{tabular}


Table 5. Locality information for Bighorn Basin and Green River Basin data used in Table 4. Localities are listed from oldest (a) to youngest (j). Bighorn Basin localities refer to numerous (1-40) sites; Green River localities are listed by name. See Wing et al. (1995) and Wilf (2000) for details.

\begin{tabular}{|c|c|c|c|c|c|c|c|}
\hline \multicolumn{4}{|c|}{ Bighorn Basin } & \multicolumn{4}{|c|}{ Mean richness of facies types } \\
\hline Localities & No. sites & NALMA & Formation & backswamp & alluvial ridge & channel & pond \\
\hline a & 7 & Puercan & Fort Union & 6 & 9 & 6 & - \\
\hline $\mathrm{b}$ & 4 & Torrejonian & Fort Union & 11 & 11 & 3 & - \\
\hline $\mathrm{c}$ & 8 & Tiffanian & Fort Union & - & 9.3 & 3 & - \\
\hline $\mathrm{d}$ & 11 & E Clarkforkian & Fort Union & 13.1 & 15.5 & - & - \\
\hline $\mathrm{e}$ & 7 & L Clarkforkian & Fort Union & 11.7 & - & - & 16 \\
\hline $\mathrm{f}$ & 33 & E Graybullian & Fort Union & 8.9 & 11.4 & 3 & - \\
\hline g & 7 & M Graybullian & Fort Union & 7 & - & - & 16.5 \\
\hline $\mathrm{h}$ & 5 & L Graybullian & Fort Union & - & - & - & 14.7 \\
\hline $\mathrm{i}$ & 1 & Lysitian & Wasatch & - & - & - & 38 \\
\hline $\mathrm{j}$ & 40 & Lostcabinian & Wasatch & 10.6 & - & 2 & - \\
\hline
\end{tabular}

\begin{tabular}{lcclll}
\hline Green River Basin & & & & \\
\hline Localities & Listed as & No. sites & NALMA & Formation & Fort Union \\
\hline Bison Basin & $\mathrm{a}$ & 14 & Tiffanian & upper Fort Union-lower Wasatch \\
Clarkforkian Big Multi & $\mathrm{b}$ & $49 \& 15$ & Clarkforkian & upper Fort Union \\
Wasatch Main Body & $\mathrm{c}$ & 6 & Graybullian-Lysitian & Wasatch-Ranger Ranch alluvial \\
Latham & $\mathrm{d}$ & 7 & Lysitian & Wasatch-upper Ranger Ranch \\
Sourdough & $\mathrm{e}$ & 31 & E Lostcabinian & Wasatch & alluvial \\
Niland Tongue & $\mathrm{f}$ & 5 & Lostcabinian & Green River
\end{tabular}

\section{Cercidiphyllaceae and Trochodendraceae}

The families Cercidiphyllaceae and Trochodendraceae are today endemic to Asia, but both have a widespread fossil record in the Tertiary of the Northern Hemisphere. Vegetative leaves of Cercidiphyllaceae have been variously referred to Cercidiphyllum and Trochodendroides, and infructescences to Nyssidium (McIver \& Basinger 1993, Crane et al. 1990), while the whole plant reconstruction of the extinct genus Joffrea has demonstrated additional variability in the fossil record (Stockey \& Crane 1983; Crane \& Stockey 1985, 1986a). In the Trochodendraceae, leaves referred to as Zizyphoides, Coccu$l u s$, and a variety of other names, are found in association with the distinctive fruits of Nordenskiodia and these fossil remains generally are accepted as representing an extinct member of the Trochodendraceae (Crane et al. 1991, but see Doweld 1998).

These leaf and fruit types all occur in Paleocene and Eocene localities, however the two families tend to be mutually exclusive of one another. Cercidiphyllaceae taxa are common at Ravenscrag, Golden Valley, Wannagan Creek, early Green River, throughout the Bighorn Basin and at the Alberta sites (dominant at Joffre
Bridge; Hoffman \& Stockey 1999) and rare at Almont (Table 4). Zizyphoides leaves are present in the Williston Basin (common at Almont and Beicegel Creek) and present only in the earliest Bighorn Basin site. Although there has been some confusion in distinguishing these leaf forms, this pattern of one taxon being present at a given site in the absence of the other appears to have some basis. One possible explanation is that the Joffrea and Nordenskioldia plants occupied similar niches. By chance, the first species that dispersed in new, favorable habitats would become established in the community and prevent the second species from becoming a major component of the flora.

\section{Palaeocarpinus}

Fossil betulaceous leaves, often placed in the genera $\mathrm{Be}$ tula or Corylites, are common components of many Paleocene-to-Eocene floras in western North America (Table 4). While some Eocene forms (e.g., Betula leopoldae of western Canada) are known with reproductive structures characteristic of true Betula (e.g., Crane \& Stockey 1986b), those of the Paleocene of North America 
and Asia are frequently found in association with Palaeocarpinus, a mosaic taxon with a combination of features seen in Corylus and Carpinus today. Three different species of Palaeocarpinus are known in the Paleocene of western North America: P. joffrensis from Munce's Hill; $P$. dakotensis from Almont and Beicegel Creek; and $P$. aspinosa from Wyoming. While this genus disappears in the Rockies and Great Basin by the end of the Paleocene, additional species of Palaeocarpinus are known in the Eocene of the Pacific Northwest and Far East Russia (Manchester et al. 2004).

\section{Conclusions}

In this paper we have presented an analysis of the major floras of the late Paleocene to early Eocene transition in North America in the context of their depositional environments. This transition is well documented in the western Rocky Mountains and the Western Interior of North America in several well-defined basins. In contrast, in eastern North America it is more difficult to define because floras of these ages are rare, and the deposition of time transgressive stratigraphic units often cannot be definitively dated.

Each of the western basins that form the basis of this paper is tectonically defined and has its own distinctive and discernable history. The paleoenvironmental conditions within each basin are the agents responsible for sampling the flora, and understanding the mode in which they do this is critical to understanding the composition of the resulting flora. For example, not all basins are dominated by large lakes; in some basins there is a wide range of fluvial and lacustrine depositional settings (Table 2). In the case of exceptionally preserved floras (e.g., Almont), an unusual set of preservational conditions provide the morphological and anatomical data for high resolution systematic context. Together these factors provide the basis for understanding the late Paleocene-early Eocene floral record and its relationships with European floras.

\section{Acknowledgements}

We thank Margaret E. Collinson for inviting our participation in this symposium and edited volume, James F. Basinger for information on stratigraphy, Steven R. Manchester for discussion, and John C. Benedict and Witt Taylor for editorial assistance, and Felix Gato and Wegener and Rodney DeVore for technical assistance. We are especially grateful to the collaborators of the Paleobiology Database for providing databases on the floras of R. Brown and others, and to Jane Maienschein for encouragement. Funding for this work was provided by NSF EAR-0345838 to KBP and NSF EAR- 0345569 , and a Faculty Research and Development Award, GC\&SU, and a Visiting Professorship from the Center of Biology \& Society, School of Life Sciences, Arizona State University, to MLD.

\section{References}

ARNOLD, C.A. 1955. A Tertiary Azolla from British Columbia. Contributions of the Museum of Paleontology of the University of Michigan 12, 37-45.

Barton, K.E., Howell, D.G. \& Vigil, J.F. 2009. The North America tapestry of time and terrain. United States Geological Survey, Geologic Investigations Series I-2781, http://pubs.usgs.gov/imap/i2781/ (accessed 27 October, 2009).

BASINGER, J.F. 1981. The vegetative body of Metasequoia milleri from the Middle Eocene of southern British Columbia. Canadian Journal of Botany 59, 2379-2410.

BASINGER, J.F. 1984. Seed cones of Metasequoia milleri from the middle Eocene of southern British Columbia. Canadian Journal of Botany 62(2), 281-289. DOI 10.1139/b84-045

BASINGER, J.F. \& ROTHWELL, G.W. 1977. Anatomically preserved plants from the Middle Eocene (Allenby Formation) of British Columbia. Canadian Journal of Botany 54, 2379-2410.

BeCK, R.A., VondRa, C.F., Filkins, J.E. \& Olander, J.D. 1988. Syntectonic sedimentation and Laramide basement thrusting, Rocky Mountain foreland: timing and deformation, 465-487. In SCHMIDT, C.J. \& PERRY, W.J. (eds) Interaction of the Rocky Mountain Foreland and Cordilleran thrust belt. Geological Society of America Memoir 171.

Belt, E.S., HaRtMAn, J.H., DiEMER, J.A., KROEger, T.J., TIBERT, N.E. \& CURRAN, H.A. 2004. Unconformities and age relationships, Tongue River and older members of the Fort Union Formation (Paleocene), western Williston Basin, U.S.A. Rocky Mountain Geology 39(2), 113-140.

DOI 10.2113/39.2.113

Benedict, J.C., PIGG, K.B. \& DeVore, M.L. 2008. Hamawilsonia boglei gen. et sp. nov. (Hamamelidaceae) from the Late Paleocene Almont flora of central North Dakota, USA. International Journal of Plant Sciences 169(5), 687-700. DOI $10.1086 / 533607$

Benedict, J.C., Taylor, W., Pigg, K.B. \& DeVore, M.L. 2007. Late Paleocene seeds from Beicegel Creek (McKenzie County, North Dakota, USA) with affinities to the genus Spirematospermum Chandler (Zingiberales). Botany \& Plant Biology 2007 (Chicago, July 2007), Abstract.

BROUGHTON, P.I. 1979. Origin of coal basins by salt solution tectonics in western Canada. Ph.D. thesis, University of Cambridge, Cambridge U.K.

BRown, R.W. 1962. Paleocene floras of the Rocky Mountains and Great Plains. United States Geological Survey Professional Paper 375. Department of the Interior, Washington, DC.

Brown, T.M. \& KraUS, M.J. 1981. Lower Eocene alluvial paleosols (Willwood Formation, Northwest Wyoming, U.S.A.) and their significance for paleoecology, paleoclima- 
tology and basin analysis. Palaeogeography, Palaeoclimatology, Palaeoecology 34, 1-30. DOI 10.1016/0031-0182(81)90056-0

BUNKER, B.J., WiTZKE, B.J., WATNEY, W.L. \& LUDVIGSON, G.A. 1988. Phanerozoic history of the central midcontinent, United States, 243-260. In SLOSS, L.L. (ed.) The Geology of North America, D-2. The Geological Society of America, Boulder.

ChandraseKharam, A. 1974. Megafossil flora from the Genesee locality, Alberta, Canada. Palaeontographica Abteilung B 147, 1-47.

CHEN, I., MANCHESTER, S.R. \& CHEN, Z. 2004. Anatomically preserved seeds of Nuphar (Nymphaeaceae) from the Early Eocene of Wutu, Shandong Province, China. American Journal of Botany 91(8), 1265-1272. DOI 10.3732/ajb.91.8.1265

CleChENKO, R.C., Kelly, D.C., HARRINGTON, G.J. \& STILES, C.A. 2007. Terrestrial records of a regional weathering profile at the Paleocene-Eocene boundary in the Williston Basin of North Dakota. Geological Society of America Bulletin 119(3/4), 428-442. DOI 10.1130/B26010.1

Clyde, W.C., Hamzi, W., Finarelli, J.A., Wing, S.L., SCHANKLER, D. \& CHEW, A. 2007. Basin-wide magnetostratigraphic framework for the Bighorn Basin, Wyoming. Geological Society of America Bulletin 119, 848-859. DOI 10.1130/B26104.1

CRANE, P.R., MANCHESTER, S.R. \& DILCHER, D.L. 1988. Morphology and phylogenetic significance of the angiosperm Platanites hebridicus from the Paleocene of Scotland. Palaeontology 31, 503-517.

Crane, P.R., Manchester, S.R. \& Dilcher, D.L. 1990. A preliminary survey of fossil leaves and well-preserved reproductive structures from the Sentinel Butte Formation (Paleocene) near Almont, North Dakota. Fieldiana, Geology, New Series No. 20, Publication 1418, 1-63.

CRANE, P.R., MANChESTER, S.R. \& DILChER, D.L. 1991. Reproductive and vegetative structure of Nordenskioldia (Trochodendraceae), a vesselless dicotyledon from the early Tertiary of the Northern Hemisphere. American Journal of Botany 78(10), 1311-1334. DOI 10.2307/2445271

CRANE, P.R. \& STOCKEY, R.A. 1985. Growth and reproductive biology of Joffrea speirsii gen. et sp. nov., a Cercidiphyllum-like plant from the Late Paleocene of Alberta, Canada. Canadian Journal of Botany 63, 340-364.

CRANE, P.R. \& STOCKEY, R.A. 1986a. Morphology and development of pistillate inflorescences in extant and fossil Cercidiphyllaceae. Annals of the Missouri Botanical Garden 73(2), 382-393. DOI 10.2307/2399118

CRANE, P.R. \& STOCKEY, R.A. 1986b. Betula leaves and reproductive structures from the Middle Eocene of British Columbia, Canada, Canadian Journal of Botany 65, 2490-2500. DOI $10.1139 / \mathrm{b} 87-338$

DANEHY, D.R., WiLf, P. \& LitTLE, S.A. 2007. Early Eocene macroflora from the Red Hot Truck Stop locality (Meridian, Mississippi, USA). Palaeontological Electronica 10(3), 17A, $1-31$.
DAVIES-VOLLUM, K.S. \& WING, S.L. 1998. Sedimentological, taphonomic, and climatic aspects of Eocene swamp deposits (Willwood Formation, Bighorn Basin, Wyoming). Palaios 13(I), 28-40. DOI 10.2307/3515279

DECELLES, T.C. 1994. Late Cretaceous-Paleocene synorogenic sedimentation and kindematic history of the Sevier thrust belt, northeast Utah and southwest Wyoming. Geological Society of America Bulletin 106, 32-56.

DOI 10.1130/0016-7606(1994)106<0032:LCPSSA>2.3.CO;2

Demchuck, T., CAMERON, A.R. \& Hills, L.V. 1991. A re-examination of the Paskapoo Formation in the central Alberta Plains: the designation of three new members. Bulletin of $\mathrm{Ca}$ nadian Petroleum Geology 39, 270-282.

DEVoRE, M.L. \& PIGG, K.B. 2008. Aquatic plants of the Eocene Republic, Washington flora and their significance to interpreting ancient lacustrine environments. Symposium: What Good are (Fossil) Plants Anyway? New Methods for Investigating Old Problems. Geological Society of America, Houston, October 2008, Paper No. 126-3, Abstracts.

DeVore, M.L., Sullivan, A.L. \& PigG, K.B. 2004. Monocots from the Late Paleocene of North Dakota. U.S.A. Botany 2004, Abstracts.

DowelD, A.B. 1998. Carpology, seed anatomy and taxonomic relationships of Tetracentron (Tetracentraceae) and Trochodendron (Trochodendaceae). Annals of Botany 82, 413-443. DOI 10.1006/anbo.1998.0679

ERICKSON, B.R. 1991. Flora and fauna of the Wannagan Creek Quarry: Late Paleocene of North America. Scientific Publications of the Science Museum of Minnesota New Series 7(3), 5-19.

FAldeR, A.B., Stockey, R.A. \& Rothwell, G.W. 1999. In situ fossil seedlings of a Metasequoia-like taxodiaceous conifer from Paleocene river floodplain deposits of central Alberta, Canada. American Journal of Botany 86(6), 900-902. DOI $10.2307 / 2656710$

FISCHER, A.G. 1953. Geology of west central McKenzie County, North Dakota. North Dakota Geological Survey Report Inventory 11, 1 sheet.

FlORES, R.M., RoberTs, S.B. \& PERRY, W.J., JR. 1994. Paleocene paleogeography of the Wind River, Bighorn, and Powder River basins, Wyoming, 1-16. In FlORES, R.M., MEHRING, K.T., JONES, R.W. \& BECK, T.L. (eds) Organics and the Rockies Field Guide. Public Information Circular 33. Wyoming Geological State Survey.

FRANK, M.C. \& BEND, S.L. 2004. Peat-forming history of the ancestral Souris mire (Paleocene), Ravenscrag Formation, southern Saskatchewan, Canada. Canadian Journal of Earth Sciences 41, 307-322. DOI 10.1139/e04-002

GEMMILL, C.E. \& JOHNSON, K.R. 1997. Paleoecology of a late Paleocene (Tiffanian) megaflora from the northern Great Divide Basin. Palaios 12(5), 439-448.

DOI 10.2307/3515382

GERHARD, L.C., ANDERSON, S.B., LEFEVER, J.A. \& CARLSON, C.G. 1982. Geological development, origin, and energy mineral resources of Williston Basin, North Dakota. 
American Association of Petroleum Geologists 66(8), 989-1020.

GINGERICH, P.D. 1983. Paleocene-Eocene faunal zones and a preliminary analysis of Laramide structural deformation in the Clark's Fork Basin, Wyoming. Wyoming Geological Association Guidebook of the $34^{\text {th }}$ Annual Field Conference, 185-195.

GrahAM, A. 1999. Late Cretaceous and Cenozoic history of North American vegetation. 350 pp. Oxford University Press, Oxford.

HAMILTON, W.B. 1988. Laramide crustal shortening. Geological Society of America Memoir 171, 27-38.

HARRINGTON, G.J. 2003. Wasatchian (Early Eocene) pollen floras from the Red Hot Truck Stop, Mississippi, USA. Palaeontology 46(4), 725-738. DOI 10.1111/1475-4983.00318

HARRINGTON, G.J. 2004. Structure of the North American vegetation gradient during the late Paleocene/early Eocene warm climate. Evolutionary Ecology Research 6, 33-48.

HARrington, G.J. 2008. Comparisons between PalaeoceneEocene paratropical swamp and marginal marine pollen floras from Alabama and Mississippi, USA. Palaeontology 51(3), 611-622. DOI 10.1111/j.1475-4983.2008.00768.x

Harrington, G.J., Clechenko, E.R. \& Kelly, D.C. 2005. Palynology and organic-carbon isotope ratios across a terrestrial Palaeocene/Eocene boundary section in the Williston Basin, North Dakota, USA. Palaeogeography, Palaeoclimatology, Palaeoecology 226(3-4), 214-232.

DOI 10.1016/j.palaeo.2005.05.013

HARrington, G.J. \& JARAMILlO, C.A. 2007. Paratropical floral extinction in the Late Palaeocene-Early Eocene. Journal of the Geological Society of London 164, 323-332. DOI 10.1144/0016-76492006-027

HE, S.-A., YIN, G. \& PANG, Z-J. 1997. Resources and prospects of Ginkgo biloba in China, 373-383. In HORI, T., RIDGE, R.W., TUlecke, W., DEL TredicI, P., TremouillauXGuller, J. \& TOBE, H. (eds) Ginkgo biloba: a global treasure. Springer, Tokyo.

HICKEY, L.J. 1977. Stratigraphy and paleobotany of the Golden Valley Formation (Early Tertiary) of western North Dakota. The Geological Society of America Memoir 150, 1-181.

HICKEY, L.J. 1980. Paleocene stratigraphy and flora of the of the Clark's Fork Basin, 33-49. In GINGERICH, P.D. (ed.) Early Cenozoic paleontology and stratigraphy of the Bighorn Basin, Wyoming. University of Michigan Museum of Paleontology, Volume 24.

HICKEY, L.J. \& PETERSON, R.K. 1978. Zingiberopsis, a fossil genus of the ginger family from Late Cretaceous to Early Eocene sediments in Western Interior North America. Canadian Journal of Botany 56, 1136-1152. DOI 10.1139/b78-128

HoffMAN, G.L. 2002. Paleobotany and paleoecology of the Joffre Bridge Roadcut locality (Paleocene), Red Deer, Alberta. $2^{\text {nd }}$ edition. M.Sc. thesis, University of Alberta, Edmonton, Alberta.

HoffMAN, G.L. \& Stockey, R.A. 1994. Sporophytes, mega- spores, and massulae of Azolla stanleyi from the Paleocene Joffre Bridge locality, Alberta. Canadian Journal of Botany 72(3), 301-308. DOI 10.1139/b94-039

HofFMAN, G.L. \& STOCKEY, R.A. 1997. Morphology and paleoecology of Ricciopsis speirsae sp. nov. (Ricciaceae), a fossil liverwort from the Paleocene Joffre Bridge locality, Alberta, Canada. Canadian Journal of Botany 75(8), 1375-1381. DOI 10.1139/b97-851

HoffMAN, G.L. \& STOCKeY, R.A. 1999. Geological setting and paleobotany of the Joffre Bridge Roadcut fossil locality (Late Paleocene), Red Deer Valley, Alberta. Canadian Journal of Earth Science 3, 2073-2084.

DOI 10.1139/cjes-36-12-2073

INGRAM, S.L. 1991. The Tuscahoma-Bashi section at Meridian, Mississippi: first notice of lowstand deposits above the Paleocene-Eocene TP2/TE1 sequence boundary. Mississippi Geology 11, 9-14.

JACOB, A.F. 1972. Depositional environments in parts of the Tongue River Formation, western North Dakota, 43-63. In TING, F.T.C. (ed.) Depositional environments of the lignitebearing strata in western North Dakota. North Dakota Geological Survey Miscellaneous Series 50.

JOHNSON, K.R. 1992. Leaf-fossil evidence for extensive floral extinction at the Cretaceous-Tertiary boundary, North Dakota, USA. Cretaceous Research 13, 91-117.

DOI 10.1016/0195-6671(92)90029-P

JOHNSON, K.R. 2002. Megaflora of the Hell Creek and lower Fort Union Formations in the western Dakotas: Vegetational response to climate change, the Cretaceous-Tertiary boundary event, and rapid marine transgression, 329-392. In HARTMAN, J.H., JOHNSON, K.R. \& NiCHOLS, D.J. (eds) The Hell Creek Formation and the Cretaceous-Tertiary Boundary in the Northern Great Plains: An integrated continental record of the end of the Cretaceous. Special Paper 361. The Geological Society of America, Boulder.

JOHNSON, K.R. \& ELLIS, B. 2002. A tropical rainforest in Colorado 1.4 million years after the Cretaceous-Tertiary boundary. Science 296, 2379-2383.

DOI 10.1126/science.1072102

JOHNSON, R.C. \& FLORES, R.M. 1998. Developmental geology of coalbed methane from shallow to deep in Rocky Mountain basins and in Cook Inlet-Matanuska Basin, Alaska, U.S.A. and Canada. International Journal of Coal Geology 35(1-4), 241-282. DOI 10.1016/S0166-5162(97)00016-5

JOY, K.W., WILLIS, A.J. \& LACEY, W.S. 1956. A rapid cellulose peel technique in palaeobotany. Annals of Botany (London), NS 20, 635-637.

KVAČEK, Z., MANCHESTER, S.R. \& GUO, SHUANG-XING 2001. Trifoliolate leaves of Platanus bella (Heer) comb. n. from the Paleocene of North America, Greenland, and Asia and their relationships among extinct and extant Platanaceae. International Journal of Plant Sciences 162(2), 441-458.

KVAČEK, Z. \& MANCHESTER, S.R. 1999. Eostangeria Barthel (extinct Cycadales) from the Paleogene of western North 
America and Europe. International Journal of Plant Sciences 160(3), 621-629. DOI 10.1086/314152

Kittle, A., DeVore, M.L., Wall, B. \& PigG, K. 2005. Acer fruits from the Paleocene of North Dakota. Georgia Academy of Sciences. Journal 63, 32.

KNOWLTON, F.H. 1893. Notes on a few fossil plants from the Fort Union group of Montana, with a description of one new species. United States National Museum Proceedings 16, 33-36.

KnOwLton, F.H. 1919. A catalogue of the Mesozoic and Cenozoic plants of North America. United States Geological Survey Bulletin 696, 1-815.

LESQUEREUX, L. 1874. The lignitic formation and its fossil flora. United States Geological Survey of the Territories Annual Report (1893)7, 365-425.

LESQUEREUX, L. 1878. Contributions to the flora of the Western Territories. II. The Tertiary flora. Reports of the United States Geological Survey of the Territories 7, 1-366.

MANCHESTER, S.R. 2001. Leaves and fruits of Aesculus (Sapindales) from the Paleocene of North America. International Journal of Plant Science 162(4), 985-998. DOI $10.1086 / 320783$

MANCHESTER, S.R. 2002a. Leaves and fruits of Davidia (Cornales) from the Paleocene of North America. Systematic Botany $27(2), 368-382$.

MANCHESTER, S.R. 2002b. Morphology and phytogeographic history of Porosia Hickey in the Cretaceous and Paleocene of Asia and North America, and its distinction from Limnobiophyllum Krassilov, 180-181. In AKHMETIEV, M.A., DOLUDENKo, M.P., HERMAN, A.B. \& IGNATIEV, A.I. (eds) Special volume, dedicated to the memory of the Corresponding member of the USSR Academy of Sciences, Professor Vsevolod Andreevich Vakhrameev (to the $90^{\text {th }}$ anniversary of his birth). Geological Institute Russian Academy of Sciences, Moscow.

MAnchester, S.R., AKhMEtiev, M.A. \& KodRUl, T.M. 2002. Leaves and fruits of Celtis aspera (Newberry) comb. nov. (Celtidaceae) from the Paleocene of North America and eastern Asia. International Journal of Plant Sciences 163(5), 725-736. DOI 10.1086/341513

MANCHESTER, S.R. \& CHEN, Z.D. 1996. Palaeocarpinus aspinosa sp. nov. (Betulaceae) from the Paleocene of Wyoming, USA. International Journal of Plant Sciences 157(5), 644-655. DOI 10.1086/297386

MANCHESTER, S.R. \& CHEN, Z.D. 1998. A new genus of Coryloideae (Betulaceae) from the Paleocene of North America. International Journal of Plant Sciences 159(3), 522-532. DOI 10.1086/297569

MANCHESTER, S.R., CHEN, Z.D., LU, A.M., UEMURA, K. 2009. Eastern Asian endemic seed plant genera and their paleogeographic history throughout the Northern Hemisphere. Journal of Systematics and Evolution 47 (1), 1-42.

MANCheSter, S.R., CRANE, P.R. \& GolovneVA, L.B. 1999. An extinct genus with affinities to extant Davidia and Camptotheca (Cornales) from the Paleocene of North America and eastern Asia. International Journal of Plant Sciences 160(1), 188-207. DOI 10.1086/314114

MANCHESTER, S.R. \& DILCHER, D.L. 1982. Pterocaryoid fruits (Juglandaceae) in the Paleogene of North America and their evolutionary and biogeographic significance. American Journal of Botany 69(2), 275-286. DOI 10.2307/2443015

MANCHESTER, S.R. \& DILCHER, D.L. 1997. Reproductive and vegetative morphology of Polyptera (Juglandaceae) from the Paleocene of Wyoming and Montana. American Journal of Botany 84(5), 649-663. DOI 10.2307/2445902

MANCHESTER, S.R. \& HICKEY, L.J. 2007. Reproductive and vegetative organs of Browniea gen. n. (Nyssaceae) from the Paleocene of North America. International Journal of Plant Sciences 168(2), 229-249. DOI 10.1086/509661

MAnChester, S.R., PIGG, K.B. \& CRANe, P.R. 2004. Palaeocarpinus dakotensis sp. nov. (Betulaceae: Coryloideae) and associated staminate catkins, pollen and leaves from the Paleocene of North Dakota. International Journal of Plant Sciences 165(6), 1135-1148. DOI 10.1086/423870

MANCHESTER, S.R., \& ZAVADA, M.S. 1987. Lygodium foliage with intact sorophores from the Eocene of Wyoming. Botanical Gazette 148 (3), 392-399.

Matthews, T., DeVore, M.L. \& PIGG, K. 2006. Paleocene pteridophytes from the siliceous shales of western North Dakota. $23^{\text {rd }}$ Annual Midcontinent Paleobotanical Colloquium, Florida Museum of Natural History, University of Florida, Gainesville, Florida, March 10-12, 2006, Abstract.

Matthews, T., PigG, K.B., DeVore, M.L. \& Rhode, J. 2007. Anatomically preserved Isoetes from the Paleocene of North Dakota: utility in ascertaining paleohabitat. Geological Society of America Abstracts with Programs 39(2), 29.

MCIVER, E.E. \& BASINGER, J.F. 1993. Flora of the Ravenscrag Formation (Paleocene), southwestern Saskatchewan, Canada. Palaeontographica Canadiana 10, 1-167.

MELCHIOR, R.C. \& HALL, J.W. 1983. Some megaspores and other small fossils from the Wannagan Creek site (Paleocene), North Dakota. Palynology 7, 133-145.

NEWBERRY, J.S. 1868. Notes on the later extinct floras of North America with descriptions of some new species of fossil plants from the Cretaceous and Tertiary strata. Annals of the Lyceum of Natural History, New York 9, 1-76.

Nichols, D.J. \& Johnson, K.R. 2008. Plants and the K-T boundary. 280 pp. Cambridge Paleobiology Series, Cambridge University Press, Cambridge.

PERRY, W.J., JR., WEAVER, J.N., Flores, R.M., ROBERTS, S.B. \& NiCHOLS, D.J. 1991. Sequential Laramide deformation in Montana and Wyoming. Geological Society of America Abstracts with Programs 23(4), 56.

PIGG, K.B. \& DEVore, M.L. 2003. Paleocene fruits with affinities to Actinidiaceae from the Almont and Beicegel Creek floras of North Dakota. Botany 2003, Abstracts.

PIGG, K.B. \& DeVore, M.L. 2005. Paleoactaea gen. nov. (Ranunculaceae) from the Paleogene of North Dakota and the London Clay. American Journal of Botany 92(10), 1650-1659. DOI 10.3732/ajb.92.10.1650 
PigG, K.B., DeVore, M.L. \& BREWER, M.A. 2005. Late Paleocene fruits similar to Ochna (Ochnaceae) from the Almont/Beicegel Creek floras, North Dakota, USA. Botany 2005, Austin, August 2005, Abstract.

PIGG, K.B., DeVORE, M.L. \& WoJCIECHOWSKI, M.F. 2008 a. Paleosecuridaca curtisii gen. et sp. nov., Securidaca-like samaras (Polygalaceae) from the Late Paleocene of North Dakota, USA and their significance to the divergence of families within the Fabales. International Journal of Plant Sciences 169, 1304-1313. DOI 10.1086/591981

PigG, K.B., Devore, M.L. \& WeHR, W.C. 2006. Filicalean ferns from the Tertiary of western North America: Osmunda L. (Osmundaceae: Pteridophyta), Woodwardia Sm. (Blechnaceae: Pteridophyta), and onocleoid ferns (Filicales: Pteridophyta). Fern Gazette 17, 279-286.

PigG, K.B., MANChESTER, S.R. \& DEVore, M.L. 2008b. Fruits of Icacinaceae from the Late Paleocene of western North America. American Journal of Botany 95, 824-832. DOI 10.3732/ajb.2007340

PigG, K.B. \& StockeY, R.A. 1991. Platanaceous plants from the Paleocene of Alberta, Canada. Review of Palaeobotany and Palynology 70, 125-146. DOI 10.1016/0034-6667(91)90082-E

PigG, K.B., Stockey, R.A. \& MAXwell, S.L. 1993. Paleomyrtinaea princetonensis gen. et sp. nov., permineralized myrtaceous fruits and seeds from the Princeton chert and related Myrtaceae from Almont, North Dakota. Canadian Journal of Botany 71(1), 1-9. DOI 10.1139/b93-001

RICH, F.J. 1979. The origin and development of tree islands in the Okefenokee Swamp, as determined by peat petrography and pollen stratigraphy. Ph.D. thesis, The Pennsylvania State University, University Park.

ROEHLER, H.W. 1985. Geologic map of the Kinney Rim $30 \times 60$ minute quadrangle, Wyoming and Colorado. U.S. Geological Survey Miscellaneous Investigations Map I-1615, 1 sheet, scale: $1: 100000$.

RoEHLER, H.W. 1993. Eocene climates, depositional environments, and geography, greater Green River Basin, Wyoming, Utah, and Colorado. United States Geological Survey Professional Paper $1506 \mathrm{~F}, 1-74$.

Rothwell, G.W. \& BASINGER, J.F. 1979. Metasequoia milleri n. sp., anatomically preserved pollen cones from the middle Eocene (Allenby Formation) of British Columbia. Canadian Journal of Botany 57(8), 958-970. DOI $10.1139 / \mathrm{b} 79-118$

Rothwell, G.W. \& Stockey, R.A. 1989. Fossil Ophioglossales in the Paleocene of western North America. American Journal of Botany 76(5), 637-644.

DOI $10.2307 / 2444411$

ROTHWELL, G.W. \& STOCKEY, R.A. 1991. Onoclea sensibilis in the Paleocene of North America, a dramatic example of structural and ecological stasis. Review of Palaeobotany and Palynology $70(1-2), 113-124$.

DOI 10.1016/0034-6667(91)90081-D

ROYER, D.L., Hickey, L. J. \& WING, S.L. 2003. Ecological conservatism in the "living fossil" Ginkgo. Paleobiology 29(1), 84-104.

DOI 10.1666/0094-8373(2003)029<0084:ECITLF>2.0.CO;2

SASKATCHEWAN GEOLOGICAL SURVEY (S.G.S.). 1994. Geology and mineral resources of Saskatchewan. Saskatchewan Energy and Mines, Miscellaneous Report 94-6.

STOCKEY, R.A. \& CRANE, P.R. 1983. In situ Cercidiphyllumlike seedlings from the Paleocene of Alberta, Canada. American Journal of Botany 70(12), 1564-1568.

DOI $10.2307 / 2443355$

Stockey, R.A., Rothwell, G.W. \& FALder, A.B. 2001. Diversity among taxodiaceous conifers: Metasequoia foxii sp. nov. from the Paleocene of central Alberta, Canada. International Journal of Plant Sciences 162(1), 221-234.

DOI 10.1086/317914

StOckey, R.A., HofFMAN, G.L. \& Rothwell, G.W. 1997. The fossil monocot Limnobiophyllum scutatum: resolving the phylogeny of Lemnaceae. American Journal of Botany 84(3), 355-368. DOI 10.2307/2446009

STOCKEY, R.A., LANTZ, T.C. \& RothwELL, G.W. 2006. Speirseopteris orbiculata gen. et sp. nov. (Thelypteridaceae), a derived fossil filicalean from the Paleocene of western North America. International Journal of Plant Sciences 167(3), 729-736. DOI 10.1086/501233

Sun, F. \& Stockey, R.A. 1992. A new species of Palaeocarpinus Crane based on infructescences, fruits, seeds, staminate cones and leaves from the Paleocene of Alberta, Canada. International Journal of Plant Sciences 153(1), 136-146. DOI 10.1086/297015

TAYLOR, W. 2007. Cyclocarya and its significance to the diversification of Juglandaceae. Botany \& Plant Biology 2007, Abstracts.

Taylor, W., DeVore, M.L. \& PigG, K.B. 2006. Susiea newsalemae, gen. et sp. nov. (Nymphaeaceae): Euryale-like seeds from the Late Paleocene Almont flora, North Dakota, USA. International Journal of Plant Sciences 167(6), 1271-1278. DOI 10.1086/507686

TIFFNEY, B.H. \& HAGGARD, K.K. 1996. Fruits of Mastixioideae (Cornaceae) from the Paleogene of western North America. Review of Palaeobotany and Palynology 92(6), 29-54. DOI 10.1016/0034-6667(96)00104-2

TIKOFF, B. \& MASON, J. 2001. Lithospheric buckling of the Laramide foreland during the Late Cretaceous and Paleogene. Rocky Mountain Geology 36(1), 13-35.

DOI 10.2113/gsrocky.36.1.13

TING, F.T.C. 1972. Petrified peat from a Paleocene lignite in North Dakota. Science 177, 165-166.

DOI 10.1126/science.177.4044.165

VAVREK, M.J. 2002. Palaeobotany and palaeoecology of the Munce's Hill locality near Red Deer, Alberta. B.Sc. thesis, University of Alberta, Edmonton.

WARD, L.F. 1885. Synopsis of the flora of the Laramie group. United States Geological Survey $6^{\text {th }}$ Annual Report, 399-557.

WILF, P. 2000. Late Paleocene-early Eocene climate changes in 
southwestern Wyoming: Paleobotanical analysis. Geological Society of America Bulletin 112, 292-307. DOI 10.1130/0016-7606(2000)112<0292:LPEECC >2.3.CO;2

WING, S.L. 1984. Relation of paleovegetation to geometry and cyclicity of some fluvial carbonaceous deposits. Journal of Sedimentary Petrology 54, 52-66.

WING, S.L. 1997. Global warming and plant species richness: a case study of the Paleocene/Eocene boundary, 161-185. In REAKA-KUDLA, M.L., WILSON, D.E. \& WILSON, E.O. (eds) Biodiversity II. Understanding and protecting our biological resources. Joseph Henry Press, Washington, D.C.

WING, S.L. 1998. Tertiary vegetation of North America as a context for mammalian evolution. In JANIS, C.M., SCOTT, K.M. \& JACOBS, L.L. (eds) Evolution of Tertiary mammals of North America. Volume 1: Terrestrial carnivores, ungulates, and ungulatelike mammals. Cambridge University Press, Cambridge, UK.

WING, S.L. 2000. Cool, warm, cool, warm - climate oscillation and floral change during the Paleocene-Eocene boundary interval. GFF 122(1), 182-183.

DOI 10.1080/11035890001221182

WING, S.L., ALROY, J. \& HICKEY, L.J. 1995. Plant and mammal diversity in the Paleocene to Early Eocene of the Bighorn Basin. Palaeogeography, Palaeoclimatology, Palaeoecology 115(1-4), 117-155. DOI 10.1016/0031-0182(94)00109-L
WING, S.L., BAO, H. \& KoCH, P.L. 2000. An early Eocene cooling period? Evidence for continental cooling during the warmest parts of the Cenozoic, 197-237. In HUBER, B.T., MACLEOD, K.G. \& WING, S.L. (eds) Warm climates in earth history. Cambridge University Press, Cambridge, UK.

WOLFE, J.A. 1987. An overview of the origins of the modern vegetation and flora of the northern Rocky Mountains. Annals of the Missouri Botanical Garden 74(4), 785-803. DOI $10.2307 / 2399450$

WOLFE, J.A. \& UPCHURCH, G.R., JR. 1987. Leaf assemblages across the Cretaceous-Tertiary boundary in the Raton Basin, New Mexico and Colorado. Proceedings of the National Academy of Science 84, 5096-5100. DOI 10.1073/pnas.84.15.5096

WoOd, H.E., Chaney, R.W., Clark, J., COLBERT, E.H., JePSEN, G.L., REESIDE, J.J.R. \& STOCK, C. 1941. Nomenclature and correlation of the North America continental Tertiary. Geological Society of America Special Paper 162, 1-91.

WoOdBuRne, M.O. 2004. Late Cretaceous Cenozoic mammals of North America. $2^{\text {nd }}$ edition. Columbia University Press, New York.

Xiang, (J.) Q.-Y., Shui, Y. \& Murrell, Z. 2003. Cornus eydeana (Cornaceae), a new cornelian cherry from China Notes on systematics and evolution. Systematic Botany 28(4), $757-764$. 